\title{
STOWARZYSZENIE RZYG, WESZ I SMARK. KILKA SŁÓW NA TEMAT TAKTYK TRANSLACYJNYCH STOSOWANYCH W PRZEKŁADZIE NEOLOGIZMÓW W POWIEŚCI FANTASTYCZNEJ
}

\author{
NiNA ANNA TRZASKA
}

\section{Wprowadzenie}

Niniejszy artykuł stanowi rozwinięcie kwestii poruszanej w trakcie wystąpienia pt. Kreatywność ttumacza. O translacji neologizmów w powieści fantastycznej na podstawie polskiego i greckiego przekładu „Harry'ego Pottera” wygłoszonego w ramach VIII edycji ogólnopolskiej konferencji „Język w Poznaniu” (08.04.2016). $\mathrm{W}$ referacie analizowano neologizmy i ich przekłady występujące w pierwszych trzech tomach sagi Joanne Kathleen Rowling. Poniższy tekst rozszerza problematykę odnosząc się do wszystkich części serii, co pozwala na stworzenie dokładniejszej charakterystyki technik translacyjnych oraz zweryfikowanie poprawności wyciągniętych uprzednio wniosków. Praca może również stanowić głos w dyskusji na temat kreatywnej twórczości tłumacza i przekładu jako sztuki. Ponadto, dotyczy wąskiej dziedziny wiedzy w polskiej nauce, jaką jest analiza przekładu na język nowogrecki. 


\section{Pojęcie neologizmu}

W wielu słownikach definicja neologizmu jest bardzo skrócona i ogólnikowa. W stosunkowo najbardziej dostępnym źródle, w internetowym Stowniku Języka Polskiego PWN, termin rozwinięto w następujący sposób:

neologizm «wyraz, zwrot lub znaczenie wyrazu nowo powstałe w jakimś języku»

W bardziej specjalistycznym źródle, w Tezaurusie terminologii translatorycznej (Lukszyn, 1993: 201), widnieje poniższa definicja:

Nowy w danym języku wyraz, połączenie wyrazowe lub nowe znaczenie wyrazu, połączenia wyrazowego.

Dalej podane są wyjaśnienia konkretnych typów neologizmów: neologizm autorski, neologizm derywowany, neologizm frazeologiczny, neologizm okazjonalny, neologizm semantyczny, neologizm stowotwórczy, neosemantyzm.

Nieco szerszą definicję oferuje Stownik terminów literackich (Sierotwiński, 1986: 155):

NEOLOGIZM $g$ (nowotwór językowy). Wyraz nowy, stworzony według zasad słowotwórstwa w danym języku, jeszcze nie przyswojony, wprowadzony jako propozycja z zamiarem utrwalenia (dla zastąpienia obcego słowa, nazwa pojęcia, zdefiniowany umownie termin itp.) albo tylko na doraźny użytek twórcy. Powstawanie neologizmów pozaartystycznych jest koniecznością i procesem istotnym dla żywego języka, wzbogacanego równolegle do pojawiania się nowych pojęć (np. sputnik, odrzutowiec, obrabiarka). $\mathrm{W}$ języku poetyckim nowatorstwo w tym zakresie podyktowane jest jeszcze dodatkowo dążeniem do odświeżenia środków leksykalnych, cieniowania znaczeń i zabarwienia wyrazów oraz uzyskiwania nowych efektów brzmieniowych, cechuje szczególnie niektóre okresy, kierunki i indywidualne talenty (np. twórczość B. Leśmiana).

Warto zwrócić szczególną uwagę na to, że warunkiem uznania wyrazu lub połączenia wyrazowego za neologizm jest brak notowania go przez słowniki oraz encyklopedie, przynajmniej w kontekście znaczeniowym zawartym w tekście (Chomik i Krajewska, 2011: 9).

\section{Neologizm w literaturze fantastycznej}

Przede wszystkim należy pamiętać, że neologizmy w powieściach fantastycznych stanowią pewną odrębną grupę nowotworów językowych i mają zwykle zupełnie inne właściwości niż neologizmy stosowane w poezji.

Pozycją, która doskonale opisuje specyfikę przekładu neologizmu w literaturze fantastycznej jest książka Od nominacji do kreacji. Rzecz o przekładzie neologizmów 
science fiction. Jak wskazuje tytuł, autorki interesuje głównie nurt fantastyki naukowej, jednakże część ustaleń zawartych w pracy przystaje także do omawianego gatunku.

Chomik i Krajewska (2011: 14) uznały, że neologizmy fantastyki naukowej łączą w sobie dwie funkcje - funkcję charakterystyczną dla neologizmów mowy potocznej, czyli nominację oraz funkcję charakterystyczną dla neologizmów literackich, czyli funkcję artystyczną. Przy pisaniu niniejszego artykułu przyjęto założenie, iż identyczna dwuwymiarowość obejmuje nie tylko neologizmy science fiction, ale również neologizmy wszelkiej literatury fantastycznej. Funkcja nominatywna wybranych neologizmów polega na nazwaniu obiektów i zjawisk, które nie istnieją w świecie rzeczywistym. Funkcja artystyczna polega zaś na celowym doborze środków językowych budujących ekspresywność oraz zwracaniu uwagi czytelnika na tworzywo literackie przekazu.

\section{Materiał badawczy}

Ze względu na popularność tytułu i powszechność translacji za analizowaną pozycję obrano napisaną przez J. K. Rowling siedmiotomową sagę Harry Potter reprezentującą literaturę fantastyczną. Przedmiotem badań jest porównanie neologizmów występujących w oryginale oraz przekładach na języki polski i nowogrecki ${ }^{1}$. Twórcą polskiego tłumaczenia jest Andrzej Polkowski, a grecka translacja ma dwie

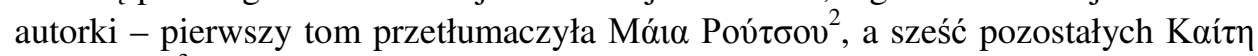
Oıкоvó $\mathrm{ov}^{3}$. Pomimo podwójnego autorstwa nowogreckiego przekładu zauważalna jest spójność rozwiązań i technik, nie ma znaczącej różnicy w lekturze poszczególnych tomów.

Uniwersum serii powieściowej jest wyjątkowo bogate, także ogólna ilość neologizmów jest imponująca. Koniecznym zabiegiem okazała się selekcja omawianych terminów. W celu uniknięcia nadmiernego subiektywizmu, za podstawę doboru wyrazów przyjęto zawarty w każdym tomie polskiego przekładu słowniczek Kilka stów od tłumacza, czyli krótki poradnik dla dociekliwych autorstwa Andrzeja Polkowskiego. W artykule zanalizowane zostaną wszystkie zawarte w nim neologizmy, czasem nieznacznie uzupełnione przez autora artykułu.

Poniższe tabele stanowią dokładny zbiór analizowanych neologizmów. Wszystkie dodatkowe terminy są uzasadnione w przypisach pod poszczególnymi tabelami. Dane książek są podane w bibliografii.

\footnotetext{
${ }^{1}$ Jako że istnieje przekład pierwszego tomu powieści również na język starogrecki należy zaznaczyć, że stosowany w dalszej części artykułu przymiotnik grecki odnosi się zawsze do języka nowogreckiego.

${ }^{2}$ Transliteracja: Maia Routsou, transkrypcja: Maja Rutsu.

${ }^{3}$ Transliteracja: Kaitī Oikonomou, transkrypcja: Keti Ikonomu.
} 
TOM PIERWSZY - HARRY POTTER AND THE PHILOSOPHER'S STONE / HARRY

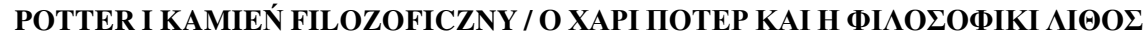

\begin{tabular}{|c|c|c|}
\hline $\begin{array}{c}\text { NEOLOGIZM } \\
\text { W J. ANGIELSKIM }\end{array}$ & $\begin{array}{c}\text { PRZEKŁAD NEOLOGIZMU } \\
\text { NA J. POLSKI }\end{array}$ & $\begin{array}{c}\text { PRZEKLAD NEOLOGIZMU } \\
\text { NA J. GRECKI }\end{array}$ \\
\hline Gryffindor & Gryffindor, Gryfon & Гкрі́фіvтор \\
\hline Hogwart & Hogwart & 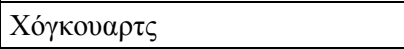 \\
\hline Hufflepuff & Hufflepuff, Puchon & X $\alpha \varphi \lambda \pi \alpha \varphi \lambda$ \\
\hline Peeves Poltergeist & Irytek Poltergeist & $\Pi 1 \beta \varsigma$ \\
\hline Quaffle & kafel & Н ко́ккıvๆ $(\mu \pi \alpha \dot{\alpha} \lambda \alpha)$ \\
\hline Muggles & mugole & o/ot М $\alpha \gamma \kappa \lambda$ \\
\hline Quidditch & Quidditch & 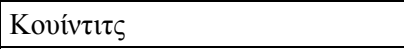 \\
\hline Ravenclaw & Ravenclaw, Krukon & 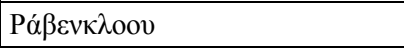 \\
\hline Slytherin & Slytherin, Ślizgon & $\Sigma \lambda i \theta \varepsilon \rho ı$ \\
\hline Bludger & Tłuczki & Oı $\mu \alpha v ́ \rho \varepsilon \varsigma(\mu \pi \alpha ́ \lambda \varepsilon \varsigma)$ \\
\hline Transmutation & Transmutacja & 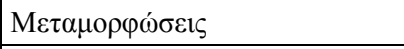 \\
\hline Diagon Alley & Ulica Pokątna & H $\Delta 1 \alpha \gamma \omega ́ v 10 \varsigma$ A $A \lambda \varepsilon \dot{\varepsilon} \alpha$ \\
\hline Snitch & (Złoty) znicz & $\mathrm{H} \chi \rho v \sigma \eta ́(\mu \pi \alpha ́ \lambda \alpha)$ \\
\hline
\end{tabular}

TOM DRUGI - HARRY POTTER AND THE CHAMBER OF SECRETS / HARRY POTTER I KOMNATA TAJEMNIC / O XAPI ПOTEP KAI H KAMAPA ME TA MYETIKA

\begin{tabular}{|c|c|c|}
\hline $\begin{array}{c}\text { NEOLOGIZM } \\
\text { W J. ANGIELSKIM }\end{array}$ & \begin{tabular}{|c|} 
PRZEKLAD NEOLOGIZMU \\
NA J. POLSKI
\end{tabular} & $\begin{array}{c}\text { PRZEKLAD NEOLOGIZMU } \\
\text { NA J. GRECKI }\end{array}$ \\
\hline Squib & Charłak & бкоví $\mu \pi$ \\
\hline Moaning Myrtle & Jęcząca Marta & 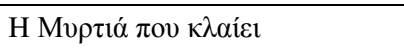 \\
\hline The Burrow & Nora & To M $\pi \alpha ́ \rho o o v$ \\
\hline Floo Powder & Proszek Fiuu & 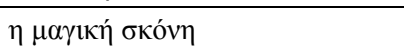 \\
\hline Mudbloods & Szlamy & $\mathrm{O} \lambda \alpha \sigma \pi \mathrm{\alpha} \alpha \dot{\mu} \mu \alpha \tau \sigma \varsigma, \eta \lambda \alpha \sigma \pi \mathrm{o \alpha i} \mu \alpha \tau \eta$ \\
\hline Knockturn & Ulica Śmiertelnego Nokturnu & $\mathrm{A} \delta \mathrm{t}^{\prime} \varepsilon \xi_{0} \delta \mathrm{o} \varsigma \mathrm{A} \lambda \bar{\varepsilon}^{\prime} \alpha$ \\
\hline Whoomping Willow & Wierzba bijąca & 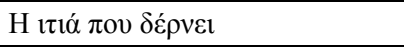 \\
\hline Kwikspell & Wmigurok & 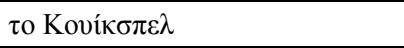 \\
\hline Dobby & Zgredek & $\mathrm{N} \tau \dot{\mu} \mu \pi \mathrm{l}$ \\
\hline
\end{tabular}

TOM TRZECI - HARRY POTTER AND THE PRISONER OF AZKABAN / HARRY POTTER

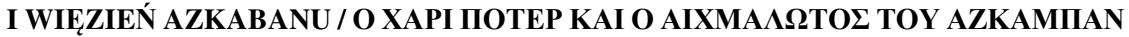

\begin{tabular}{|c|c|c|}
\hline $\begin{array}{c}\text { NEOLOGIZM } \\
\text { W J. ANGIELSKIM } \\
\end{array}$ & \begin{tabular}{|c} 
PRZEKŁAD NEOLOGIZMU \\
NA J. POLSKI
\end{tabular} & \begin{tabular}{|c} 
PRZEKLAD NEOLOGIZMU \\
NA J. GRECKI
\end{tabular} \\
\hline Animagus & Animag & 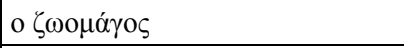 \\
\hline The Knight Bus & Błędny Rycerz & 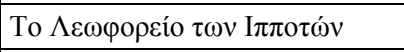 \\
\hline Firebolt & Błyskawica & 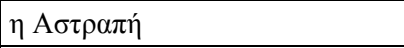 \\
\hline Boggart & Bogin & $\tau о \mu \pi \delta ́ \gamma \kappa \alpha \rho \tau$ \\
\hline Dementors & Dementorzy & ot Пара́ $\varphi \rho о v \varepsilon \varsigma$ \\
\hline
\end{tabular}




\begin{tabular}{|c|c|c|}
\hline $\begin{array}{c}\text { NEOLOGIZM } \\
\text { W J. ANGIELSKIM } \\
\end{array}$ & \begin{tabular}{|c} 
PRZEKŁAD NEOLOGIZMU \\
NA J. POLSKI
\end{tabular} & $\begin{array}{c}\text { PRZEKŁAD NEOLOGIZMU } \\
\text { NA J. GRECKI }\end{array}$ \\
\hline Gryndilow & Druzgotek & 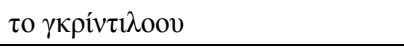 \\
\hline Sneakoscope & Fałszoskop & 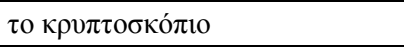 \\
\hline Gobstones & Gargulki & 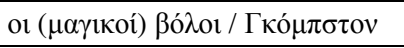 \\
\hline Wormtail & Glizdogon & O Поvтıкооvра́s \\
\hline Flobberworms & Gumochłony & 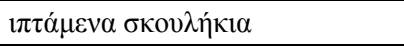 \\
\hline Buckbeak & Hardodziob & о $\Omega \rho \alpha i o ́ \rho \alpha \mu \varphi о \varsigma$ \\
\hline Hogsmeade & Hogsmeade & To Xó $\gamma \kappa \sigma \mu \imath v \tau$ \\
\hline Crookshanks & Krzywołap & о $\Sigma \tau \rho \alpha \beta$ о \\
\hline Moony & Lunatyk & 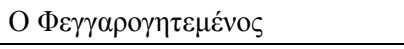 \\
\hline Dungbomb & Łajnobomba & $\eta \beta о \mu \beta \alpha$ колрı́́ \\
\hline Padfoot & Łapa & 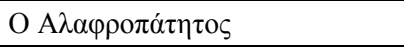 \\
\hline Ripper & Majcher & 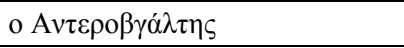 \\
\hline Marauders Map & Mapa Huncwotów & 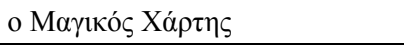 \\
\hline Honeydukes & Miodowe Królestwo & 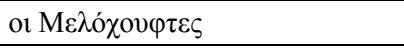 \\
\hline Butterbeer & Piwo kremowe & 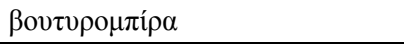 \\
\hline Grim & Ponurak & 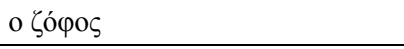 \\
\hline Prongs & Rogacz & О Е $\lambda \alpha \varphi о к \varepsilon ́ \rho \alpha \tau о \varsigma$ \\
\hline
\end{tabular}

TOM CZWARTY - HARRY POTTER AND THE GOBLET OF FIRE / HARRY POTTER

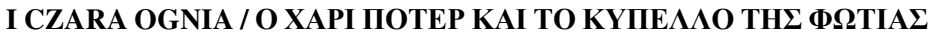

\begin{tabular}{|c|c|c|}
\hline $\begin{array}{c}\text { NEOLOGIZM } \\
\text { W J. ANGIELSKIM }\end{array}$ & \begin{tabular}{|c|} 
PRZEKLAD NEOLOGIZMU \\
NA J. POLSKI
\end{tabular} & $\begin{array}{c}\text { PRZEKLAD NEOLOGIZMU } \\
\text { NA J. GRECKI }\end{array}$ \\
\hline Auror & Auror & o $\chi \rho v \sigma o v ́ \chi o \varsigma$ \\
\hline Bubotuber & Czyrakobulwa & 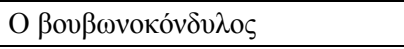 \\
\hline The Weird Sisters & Fatalne Jędze & 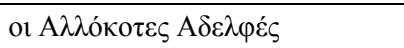 \\
\hline Ton-tongue toffi & Gigantojęzyczne Toffi & K $\alpha \rho \alpha \mu \varepsilon \dot{\lambda} \alpha-\tau$ ovó$\gamma \lambda \omega \sigma \sigma \alpha$ \\
\hline Leprechauns & Leprokonusy & 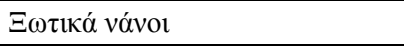 \\
\hline Winky & Mrużka & Н Гоขívкı \\
\hline Pensieve & Myślodsiewnia & 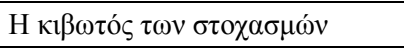 \\
\hline Niffler & Niuchacz & $\tau \mathrm{o} / \tau \alpha$ ví $\varphi \lambda \varepsilon \rho$ \\
\hline Omnioculars & Omnikulary & 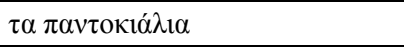 \\
\hline Blast-Ended Skrewts & Tylnowybuchowe sklątki & 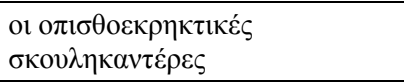 \\
\hline Gillyweed & Skrzeloziele & 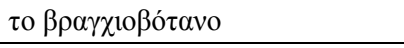 \\
\hline Hungarian Horntail* & Rogogon węgierski & 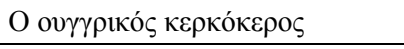 \\
\hline Common Welsh Green* & Zielony pospolity smok walijski & 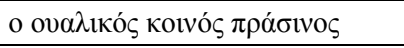 \\
\hline Swedish Short-Snout* & Szwedzki krótkopyski & 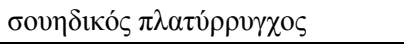 \\
\hline Chinese Fireball* & Chiński ogniomiot & 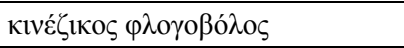 \\
\hline S.P.E.W. & Stowarzyszenie WESZ & MYEA \\
\hline
\end{tabular}




\begin{tabular}{|c|c|c|}
\hline $\begin{array}{c}\text { NEOLOGIZM } \\
\text { W J. ANGIELSKIM } \\
\end{array}$ & $\begin{array}{c}\text { PRZEKŁAD NEOLOGIZMU } \\
\text { NA J. POLSKI }\end{array}$ & $\begin{array}{c}\text { PRZEKLAD NEOLOGIZMU } \\
\text { NA J. GRECKI }\end{array}$ \\
\hline The Death Eaters & Śmierciożercy & 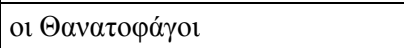 \\
\hline Portkey & Świstoklik & Н Пи́ $\lambda \eta$ \\
\hline Pigwidgeon & Świstoświnka & 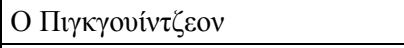 \\
\hline The Triwizard Tournament & Turniej Trójmagiczny & 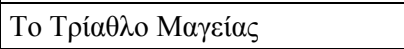 \\
\hline
\end{tabular}

* W słowniczku Polkowskiego występuje zbiorowa kategoria SMOKI, w której omawiane są wymienione w tabeli gatunki.

TOM PIĄTY - HARRY POTTER AND THE ORDER OF THE PHOENIX / HARRY POTTER I ZAKON FENIKSA / O XAPI ПOTEP KAI TO TAГMA TOY ФOINIKA

\begin{tabular}{|c|c|c|}
\hline $\begin{array}{c}\text { NEOLOGIZM W J. ANGI- } \\
\text { ELSKIM }\end{array}$ & $\begin{array}{c}\text { PRZEKŁAD NEOLOGIZMU } \\
\text { NA J. POLSKI }\end{array}$ & $\begin{array}{c}\text { PRZEKŁAD NEOLOGIZMU } \\
\text { NA J. GRECKI }\end{array}$ \\
\hline Doxys & Bahanki & 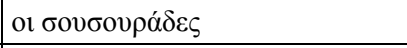 \\
\hline Skiving Snackboxes & Bombonierki Lesera & 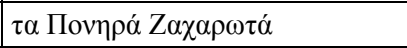 \\
\hline Puking Pastiles** & Wymiotki pomarańczowe & ol $\pi \alpha \sigma \tau i ́ \lambda 1 \varepsilon \zeta \varepsilon \mu \varepsilon \tau o u ́$ \\
\hline Fainting Fancies $* *$ & Omdlejki grylażowe & 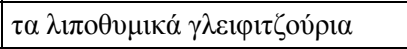 \\
\hline Noseblood Nougat** & Krwotoczki truskawkowe & 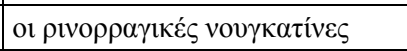 \\
\hline Crumple-Horned Snorkack & Chrapak krętorogi & 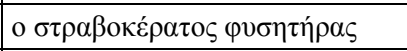 \\
\hline Colloportus & Colloportus & $\mathrm{K} \lambda \varepsilon 1 \delta \alpha \mu \pi \alpha \rho \omega ́ \sigma o v$ \\
\hline Blibbering Humdinger & Ględatek niepospolity & 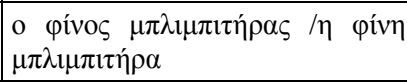 \\
\hline Legilimency & Legilimencja & $\eta \delta \imath \varepsilon \iota \delta \delta v \tau \iota \kappa \eta ́$ \\
\hline Loony*** & Pomyluna & $\eta \tau \rho \varepsilon \lambda o-\Lambda$ oúv $\alpha$ \\
\hline Metamorphmagus & Metamorfomag & о $\mu \varepsilon \tau \alpha \mu о \rho \varphi \omega \mu \alpha ́ \gamma о \varsigma$ \\
\hline Bowtruckle & Nieśmiałek & о обчvока́ $\mu \pi \tau \eta \varsigma$ \\
\hline Stinksap & Odorsok & 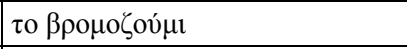 \\
\hline Occlumency & Oklumencja & $\eta \sigma \varphi \rho \alpha \gamma 1 \sigma \mu \alpha \tau \iota \kappa \eta$ \\
\hline Kreacher & Stworek & o K $\rho i ́ \tau \sigma \varepsilon \rho$ \\
\hline Knarl & Spiczak & $\tau \mathrm{o} / \tau \alpha \kappa v \alpha \rho \lambda$ \\
\hline The Order of the Phoenix & Zakon Feniksa & 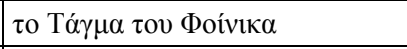 \\
\hline The Quibbler & Żongler & 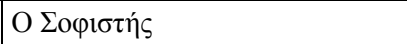 \\
\hline
\end{tabular}

**W słowniczku Polkowskiego podane nazwy są omówione w haśle zbiorczym BOMBONIERKI LESERA.

*** W słowniczku Polkowskiego omówienie przezwiska bohaterki pojawia się pod hasłem LUNA LOVEGOOD.

TOM SZÓSTY - HARRY POTTER AND THE HALF-BLOOD PRINCE / HARRY POTTER

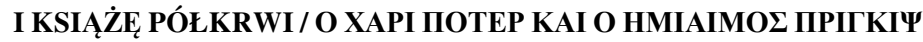

\begin{tabular}{|c|c|c|}
\hline $\begin{array}{c}\text { NEOLOGIZM } \\
\text { W J. ANGIELSKIM }\end{array}$ & $\begin{array}{c}\text { PRZEKŁAD NEOLOGIZMU } \\
\text { NA J. POLSKI }\end{array}$ & $\begin{array}{c}\text { PRZEKLAD NEOLOGIZMU } \\
\text { NA J. GRECKI }\end{array}$ \\
\hline Hokey & Bujdka & $\eta$ Хо́кı \\
\hline Felix Felicis & Felix Felicis & 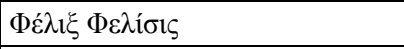 \\
\hline Wrackspurt & gnębiwtrysk & 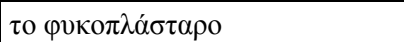 \\
\hline
\end{tabular}




\begin{tabular}{|c|c|c|}
\hline $\begin{array}{c}\text { NEOLOGIZM } \\
\text { W J. ANGIELSKIM } \\
\end{array}$ & \begin{tabular}{|c} 
PRZEKŁAD NEOLOGIZMU \\
NA J. POLSKI \\
\end{tabular} & $\begin{array}{c}\text { PRZEKŁAD NEOLOGIZMU } \\
\text { NA J. GRECKI } \\
\end{array}$ \\
\hline Horcrux & horkruks & 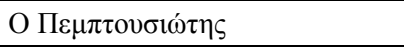 \\
\hline Inferius & inferius & 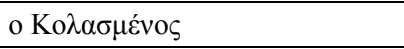 \\
\hline Slug Club & Klub Ślimaka & $\mathrm{H} \Lambda \dot{\varepsilon} \sigma \chi \eta \Sigma \lambda \alpha \gamma \kappa$ \\
\hline Nogtails & kołkogonki & 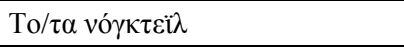 \\
\hline The Halfblood Prince & Książę Półkrwi & 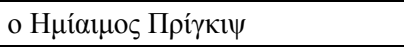 \\
\hline U-NO-POO & Q-PY BLOK & ХЕР-NA-ПON \\
\hline Sectusempra & Sectusempra & 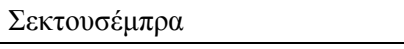 \\
\hline Snargaluffs & wnykopieńki & 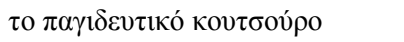 \\
\hline
\end{tabular}

TOM SIÓDMY - HARRY POTTER AND THE DEATHLY HALLOWS / HARRY POTTER I INSYGNIA ŚMIERCI / O XAPI ПOTEP KAI OI KAHPOI TOY @ANATOY

\begin{tabular}{|c|c|c|}
\hline $\begin{array}{c}\text { NEOLOGIZM } \\
\text { W J. ANGIELSKIM } \\
\end{array}$ & \begin{tabular}{|c|} 
PRZEKLAD NEOLOGIZMU \\
NA J. POLSKI
\end{tabular} & $\begin{array}{c}\text { PRZEKŁAD NEOLOGIZMU } \\
\text { NA J. GRECKI }\end{array}$ \\
\hline The Elder Wand & Czarna Różdżka & 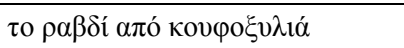 \\
\hline The Deathly Hallows & Insygnia Śmierci & 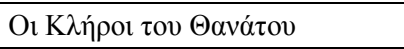 \\
\hline Trace & Namiar & 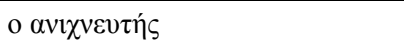 \\
\hline Snatchers & Szmalcownicy & 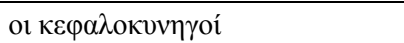 \\
\hline
\end{tabular}

\section{Metoda analizy}

Na potrzeby artykułu przyjęto podział neologizmów na poszczególne grupy, co w założeniu ma pomóc wyodrębnić techniki translatorskie przyjęte przez tłumaczy. Każdy z oryginalnych terminów zinterpretowano i rozłożono na czynniki pierwsze. Odpowiadające mu przekłady w podobny sposób zdekonstruowano i skomentowano. Kolejny etap to odnalezienie podobieństw i różnic między technikami przekładu. Może się tutaj pojawić subiektywne wartościowanie pewnych wyborów translacyjnych, oczywiście odpowiednio umotywowane (komentarze dotyczące zastrzeżeń, niespójności, niejednorodności interpretacyjnych, etc.). Ostatnim etapem jest próba odtworzenia podstawowych założeń i strategii przyjętych przez poszczególnych tłumaczy, które zebrano w podsumowaniu artykułu.

\section{Analiza}

W celu przejrzystego dokonania zestawienia, neologizmy zostały pogrupowane w następujące umowne kategorie: nazwy własne, antroponimy, bionimy i chrematonimy. Oczywiście, są to bardzo szerokie grupy, wobec czego należało również wprowadzić odpowiednie podtypy. Poszczególne kategorie onomastyczne opracowano na podstawie danych zamieszczonych na stronie Uniwersytetu Łódzkiego. 


\subsection{Nazwy własne}

Nazwy własne, inaczej onimy, to nazwy wyróżniające pojedyncze obiekty. W tej kategorii zostaną omówione nazwy indywidualne, imiona, nazwy geograficzne. Pomimo, że np. chrematonimy również można zaliczyć do onimów, jednak poświęcono im osobny podrozdział, dedykowany szeroko rozumianym wytworom materialnym i niematerialnym. W niniejszej sekcji wprowadzono następujące podtypy: nazewnictwo związane ze szkołą, imiona, przezwiska i pseudonimy oraz nazwy geograficzne.

\subsubsection{Nazewnictwo związane ze szkołą}

Pierwsza przyjęta kategoria jest dosyć problematyczna. Zalicza się do niej neologizmy Hogwart, Griffindor, Hufflepuff, Ravenclaw i Slytherin. Trudność polega na fakcie, że cztery ostatnie nazwy mają jednocześnie po trzy znaczenia. Najczęściej są to po prostu określenia szkolnych dormitoriów. Trzeba jednak pamiętać, że poza tym również stanowią potoczną nazwę dla wszystkich mieszkających w nich uczniów oraz są nazwiskami czterech legendarnych założycieli szkoły Magii i Czarodziejstwa Hogwart (Godryk Griffindor, Helga Hufflepuff, Rowena Ravenclaw i Salazar Slytherin). Oznacza to, że każdy z powyższych wyrazów to jednocześnie nazwa pomieszczenia, antroponim kolektywny i nazwisko.

Wskazane neologizmy zasadniczo nie ulegają zmianom w przekładzie, przynajmniej jeśli spojrzeć na ich podstawowe znaczenie. Jedyna różnica zachodzi w przypadku zbiorczej nazwy uczniów należących do konkretnych dormitoriów. W oryginale nie ma różnicy pomiędzy nazwą domu a nazwą jego mieszkańca. W polskim przekładzie tłumacz odniósł się do słów, które są podstawą oryginalnych neologizmów i stworzył na podstawie ich tłumaczenia polskie odpowiedniki określające poszczególne grupy studentów. I tak Gryffindor, który zawiera w sobie słowo griffin, czyli gryf, zamieszkują Gryfoni. W Ravenclaw mieszkają Krukoni, co odnosi się do zawartego w złożeniu kruka, czyli raven. W nazwie Slytherin pobrzmiewa słowo slither - ślizgać się oraz sly - szczwany, tak więc jego uczniów nazywa się zbiorczo Ślizgonami. Najbardziej enigmatyczny jest neologizm Hufflepuff, który według tłumacza zawiera w sobie onomatopeiczne leksemy chuch i pyk lub puch i puf. Z tej przyczyny w przekładzie powstał termin Puchoni. Jeśli chodzi

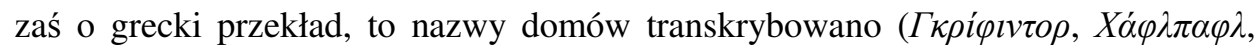
$P \alpha \dot{\beta} \varepsilon \varepsilon \kappa \lambda$ oov, $\Sigma \lambda i \theta \varepsilon \rho l v)$ i pominięto zastosowanie neologizmów w stosunku do uczniów. W rezultacie, Gryfindor, Ravenclaw, Hufflepuff i Slytherin są jedynie nazwiskami i nazwami dormitoriów, których wychowankowie są określani po prostu

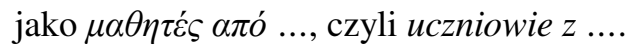

Nazwa szkoły, Hogwarts, w języku polskim pozostaje zapisywana jako Hogwart,

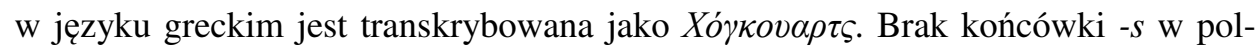


skim przekładzie można tłumaczyć częstym pomijaniem jej w mowie potocznej (por. np. sieć restauracji McDonald's).

Powyższe zestawienie wskazuje na podobne rozwiązania translatorskie w omawianych przekładach, jedyną istotną różnicą jest rozdzielenie przez polskiego tłumacza nazw dormitoriów i zamieszkujących ich uczniów.

\subsubsection{Imiona, przezwiska, pseudonimy}

Pomimo że w słowniczku Kilka słów od tłumacza... pojawia się wiele imion ludzkich, nie zostaną one szerzej omówione. Decyzja podyktowana została wyraźnym brakiem przekładu poszczególnych nazwisk, z jedynie nielicznymi wyjątkami. Do odstępstw od reguły należy przekład w języku polskim nazwiska Ministra Magii, Korneliusza Knota, który w oryginale nosi miano Cornelius Fudge. Polkowski w taki sposób tłumaczy swoją działalność (2006: 699) ${ }^{4}$ : Przyjątem zasadę niettumaczenia nazwisk (z jedynym wyjątkiem Knota, ale tu pokusa okazała się po prostu za silna!). Jednorazowo zostaje również dosłownie przetłumaczone nazwisko Syriusza Blacka, który w pierwszym tomie staje się Syriuszem Czarnym. Można w tym przypadku założyć, że tłumacz nie był pewien, czy wyraz Black stanowił nazwisko czy pseudonim. Należy zwrócić również uwagę na fakt, że Polkowski często ,spolszcza" poszczególne imiona (jak choćby wspomniani już Sirius - Syriusz i Cornelius Korneliusz). W greckim tłumaczeniu oczywiście występuje transkrypcja i transliteracja, która zmienia czasem wygląd poszczególnych imion. Przykładem może być choćby nazwisko Rona Weasleya, które, ze względu na brak w alfabecie greckim

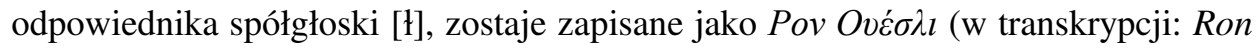
Uesli). Nie jest jednak jasne, czemu Seamus Finnigan stał się Miliganem (Líuovৎ Mílı $ү \kappa \alpha v)$.

Zupełnie inaczej ma się jednak sprawa $\mathrm{z}$ imionami istot nieludzkich, które w każdym przekładzie podlegają innym technikom translacyjnym zależnie od stopnia ich antropomorfizacji. Jeśli zwrócimy uwagę na istoty fantastyczne znacznie zbliżone do ludzi (skrzaty domowe, duchy, gobliny), to pomiędzy przekładem polskim a greckim można dostrzec ogromną rozbieżność. Z materiału badawczego można tutaj wyróżnić imiona: Peeves, Moaning Myrtle, Dobby, Winky, Kreacher i Hokey. Wszystkie z zaprezentowanych nazw mają swoje kreatywne tłumaczenie w języku polskim. Pierwsze dwie określają duchy. Złośliwy poltergeist staje się Irytkiem, od angielskiego czasownika to peeve, czyli złościć, irytować. Moaning Myrtle przechrzczono w Polsce na Martę - różnica ta wzięła się stąd, że angielskie myrtle oznacza mirt, który po polsku jest rodzaju męskiego, co kontrastowało z płcią

\footnotetext{
${ }^{4}$ Wszystkie przypisy odnoszące się do Polkowskiego dotyczą jego uwag zawartych w słowniczku Kilka stów od ttumacza, czyli krótki poradnik dla dociekliwych, ergo łączą się z polskim przekładem kolejnych tomów serii.
} 
zjawy. Pozostałe imiona należą do skrzatów domowych. Dobby, którego imię według Polkowskiego (2000: 326-327) ma oznaczać po angielsku zdziecinniatego staruszka, został mianowany Zgredkiem, co odnosi się do terminu z gwary przestępczej, ale i szkolnej, oznaczajacego godnego pogardy wapniaka. Imię Winky ma związek z czasownikiem to wink czyli mrugać, tak więc w Polsce stała się Mrużką. Imię Stworek nawiązuje do znaczenia fonetycznego skojarzenia słowa Kreacher z creature, czyli kreatura, stworem. Przekład nie niesie ze sobą tak pejoratywnego skojarzenia jak oryginał, jednakże wybór tłumacza usprawiedliwia chęć nadania podobnego brzmienia w stosunku do imion reszty skrzatów. Ostatnie skrzacie imię, Hokey, odnosi się do określenia fatszywy, co Polkowski oddał za sprawą miana Bujdka. W języku greckim natomiast prawie żadne z powyższych imion nie zostaje przełożone. Peeves, Dobby, Winky, Kreacher i Hokey zostają jedynie transkrybowane, przez co czytelnik ma do czynienia kolejno z mianami $\Pi_{\imath} \beta \varsigma, N \tau o ́ \mu \pi \imath$, Гоvívкl,

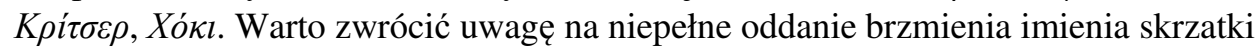
Winky, którego grecki przekład teoretycznie powinien zostać przetranskrybowany na polski jako Guinki. Jest to zwykły zabieg przy transkrypcji imion i nazwisk - jak już wspomniano, w języku greckim nie ma litery, która odpowiadałaby fonetycznie

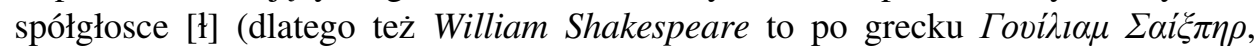
czyli Guiliam Sekspir). Jedynym wyjątkiem od reguły transkrypcji jest imię Myrtle,

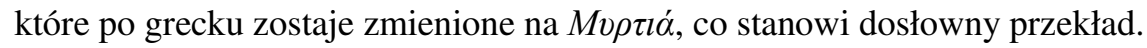

Pozostają jeszcze zoonimy - dotyczą one czasem zwierząt fantastycznych, w przypadku których ciężko mówić o jakiejkolwiek antropomorfizacji (np. hipogryf, jako hybryda konia i orła, nie przypomina wcale człowieka, nie jest również w stanie porozumiewać się w ludzkim języku). W materiale badawczym można wyróżnić cztery takie imiona: Buckbeak, Crookshanks, Ripper, Pigwidgeon. Prawie wszystkie ulegają przekładowi w obu tłumaczeniach. Hipogryf Buckbeak w Polsce jest prze-

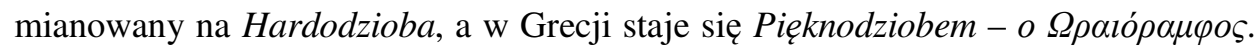
Odnosi się to do części składowych oryginalnego neologizmu: to buck - pysznić się, być buńczucznym oraz beak - dziób. Kot Hermiony, Crookshanks (powstałe na bazie złożenia crook - haczyk oraz shanks - golenie, nogi), po polsku staje się Krzywołapem, a po grecku nosi analogiczne miano o $\Sigma \tau \rho \alpha \beta o \pi o ́ \delta \alpha \rho o \varsigma$. Najciekawszym chyba jednak przypadkiem jest imię buldoga ciotki Marge, który w oryginale nosi imię Ripper, co jest oczywistym nawiązaniem do Jack the Ripper, czyli do Kuby Roz-

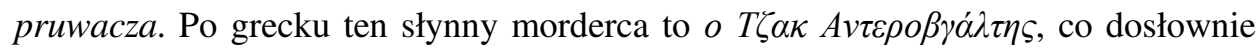
można przełożyć na Jelitowyciagacz. W greckim tłumaczeniu zachowano tę nazwę, polski tłumacz stwierdził jednak, że ciężko zawołać psa Rozpruwacz i ogłosił konkurs na imię, który wygrało miano Majcher. Nieco bardziej skomplikowana jest kwestia imienia sówki Rona - Pigwidgeon. Jest to najwyraźniej semantyczna fuzja świni (pig) i świstuna (widgeon), co zostało uwzględnione w polskim przekładzie Świstoświnka. Grecka tłumaczka przełamuje tutaj regułę i zamiast przekładu posługuje się transkrypcją - Пıүкүoviv $\tau \zeta \varepsilon o v$. 
Pozostaje jeszcze zagadnienie przezwisk i pseudonimów. Do przezwisk można zaliczyć Moaning Myrtle i Loony, które są w wyraźny sposób nacechowane pejoratywnie. Za pseudonimy uznano imiona twórców Mapy Huncwotów: Wormtail, Moony, Padfoot, Prongs oraz przydomek Severusa Snape'a - the Halfblood Prince.

Określenie zjawy Myrtle odnosi się do jej histerycznego charakteru i pochodzi od czasownika to moan -jęczeć. W polskim i greckim przekładzie można zauważyć dwie różne tendencje przekładu nazw, które w oryginale zawierają w sobie cząstkę -ing (por. fitonim Whoomping Willow). Po polsku te nazwy zostały oddane za pomocą konstrukcji ,imiesłów przymiotnikowy + rzeczownik” - Jęcząca Marta, a po grecku pojawia się natomiast konstrukcja ,rzeczownik + zaimek przymiotny + cza-

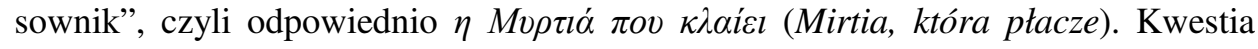
pozostaje dosyć enigmatyczna, ponieważ równie dobrze można byłoby w wokabularzu greckim użyć określenia $\kappa \lambda \alpha \psi l \alpha ́ \rho \alpha$, czyli beksa. Jeśli chodzi zaś o złośliwe określenie Luny Lovegood, to rzeczony neologizm opiera się na podobieństwie brzmienia imienia Luny do wyrazu oznaczającego pomyleńca lub dziwaka - loony. Twórca polskiego przekładu oddał grę słów obwołując bohaterkę Pomyluna. W greckim tłumaczeniu zrezygnowano $\mathrm{z}$ analogicznej figury stylistycznej i dodano do imienia przedrostek wskazujący na zbzikowanie: $\tau \rho \varepsilon \lambda o ́ \varsigma$ - szalony, czego rezultatem jest określenie $\eta \tau \rho \varepsilon \lambda o$-イov́v $\alpha$. Takie rozwiązanie może wywoływać pewne kontrowersje, ponieważ nazbyt kojarzy się z przekładem przydomku Szalonookiego Moo-

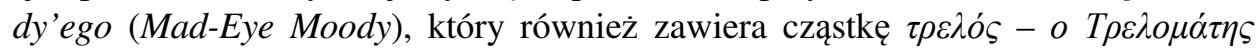

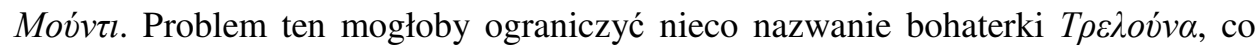
nadal zawierałoby konkretną cząstkę, jednakże fuzja z imieniem nieco osłabiłaby efekt podobieństwa.

Przechodząc do pseudonimów, to pierwszy z nich, Wormtail, stanowi dosyć oczywiste złożenie słów oznaczających robaka i ogon. Polski przekład oddaje je wiernie za pomocą analogicznego złożenia Glizdogon. W języku greckim również

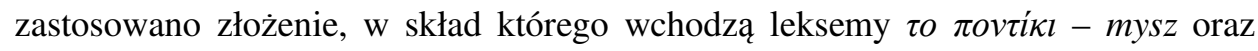

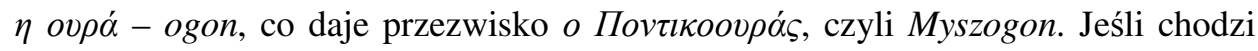
o przekład słowa Moony, to w języku polskim skorzystano z lunarnego wymiaru nazwy, co w konsekwencji stworzyło Lunatyka. Grecki ekwiwalent pochodzi od

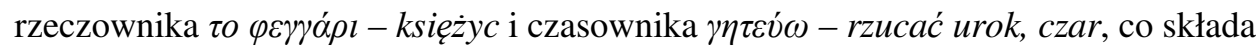

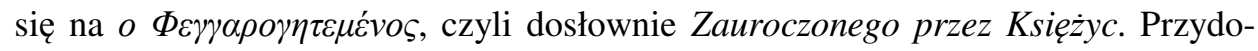
mek Syriusza, Padfoot, pochodzi od złożenia słów to pad, czyli stapać oraz foot czyli stopy. Warto jednak pamiętać, że pad to też poduszeczka na łapie zwierzęcia i zapewne stąd wzięła się polska wersja przezwiska - Łapa. Warto zaznaczyć, że Polkowski przyznał, że żałuje przekładu przydomku w takiej formie, wolałby użyć terminu Powsinoga (Orliński: 2004). W Grecji zrobiono z Syriusza Lekko Stapaja-

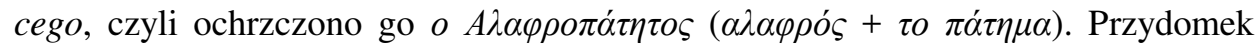
ostatniego z twórców Mapy Huncwotów, Prongs, odnosi się w oryginale do słów takich jak ząb widelca lub widet czy odnoga poroża jelenia. W polskim przekładzie 
wykorzystano konotację z porożem, więc pojawił się niejednoznaczny skojarzeniowo Rogacz. Problem z tym tłumaczeniem jest taki, że w mowie potocznej rogacz to mężczyzna zdradzany przez kobietę. W języku greckim również skoncentrowano się na nazwie nawiązującej do jelenia, wobec czego James Potter stał się Jeleniorogim -

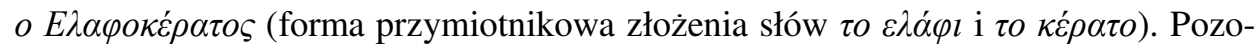
staje już tylko przydomek Severusa Snape'a, czyli Halfblood Prince. Opiera się on na nieprzekładalnej grze słów - panieńskie imię matki Snape’a brzmiało Prince, czyli książę, a sam bohater był z pochodzenia pół-czarodziejem, pół-mugolem. Polkowski pozostaje przy Księciu Pótkrwi, a etymologię nazwy wyjaśnia szerzej w słowniczku dołączonym do piątego tomu (Polkowski, 2006: 699). Określenie

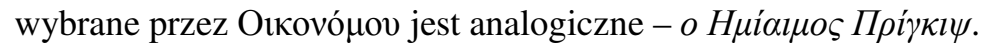

Należy zwrócić tutaj uwagę na pewne prawidłowości. Imiona bohaterów ludzkich nie są przekładane ani w Polsce, ani w Grecji. Zoonimy w dużej mierze są tłumaczone w obu wersjach językowych. Zasadniczą różnicę stanowi kwestia imion istot nieludzkich, choć w dużej mierze poddanych antropomorfizacji (duchy, skrzaty domowe). Polkowski przekłada te nazwy, natomiast greckie tłumaczki dosyć konsekwentnie obstają jedynie przy transkrypcji. Przezwiska i pseudonimy ulegają translacji w obu językach. Warto jeszcze zauważyć różnicę w przekładzie nazw, oryginalnie zawierających $\mathrm{w}$ sobie cząstkę -ing. W polskim jest to konstrukcja typu „,imiesłów przymiotnikowy + rzeczownik”, w grece natomiast - „rzeczownik + zaimek przymiotny + czasownik".

\subsubsection{Nazwy geograficzne}

W słowniczku załączonym do piątego tomu, pod hasłem Magnolia Crescent Polkowski (2004: 953) pisze:

MAGNOLIA CRESCENT - (czytaj: Megneoulie Kresnt) nazwa jednej z uliczek w Little Whinging, która w trzecim tomie została przeze mnie przełożona (Magnoliowy Łuk). Była to z mojej strony niekonsekwencja, ponieważ nie tłumaczę nazw ulic mugolskich (por. Privet Drive, Magnolia Road w tej samej miejscowości, Charing Cross Road czy Vauxhall Road w Londynie), tylko nazwy ulic w świecie czarodziejów (Pokątna, Śmiertelnego Nokturnu). Dlatego postanowiłem w tym tomie naprawić błąd i wrócić do nazwy oryginalnej.

Podobne podejście cechuje greckie autorki, które również zajmują się tłumaczeniem jedynie nazw ulic świata czarów. Na tej podstawie, zamieszczone w materiale badawczym Diagon Alley i Knockturn mają swoje odpowiedniki w obu omawianych

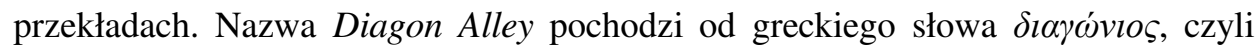
przekątny. Nie powinno więc dziwić, że w greckim tłumaczeniu funkcjonuje analogiczna $\triangle \iota \alpha \gamma \omega ́ v ı o \varsigma ~ A \lambda \varepsilon ́ \alpha$, która w polskim tłumaczeniu ewoluowała w Ulicę Pokatną. 
Nieco bardziej problematycznym przekładem jest drugi pojawiający się $\mathrm{w}$ bazie toponim - Knockturn. Stanowi on fuzję słów to knock - zbić, powalić kogoś oraz nocturne - nokturn. Jako że gra słów jest nieprzetłumaczalna, polska Ulica Śmiertelnego Nokturnu jest fonetycznym nawiązaniem do oryginalnej nazwy. Grecka

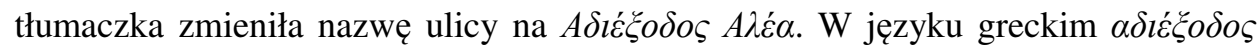
oznacza $\chi \omega \rho i ́ \varsigma ~ \delta l \varepsilon ́ \xi o \delta o$, czyli bez wyjścia. Grecką nazwę więc można oddać jako Ślepy Zautek. Nie ma to bezpośredniego związku z oryginalną nazwą, ale za zaletę można odczytać jej pejoratywny wydźwięk.

Inną istotną nazwą geograficzną jest nazwa wioski zamieszkanej przez społeczność czarodziejów Hogsmeade. W nazwie tej pobrzmiewają wyrazy hog - wieprz, meadow - taka oraz mead - miód pitny. W każdym z omawianych przekładów bra-

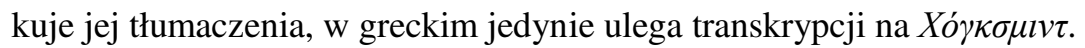

W końcu, ważną lokalizację stanowi także the Burrow, czyli nazwa domu

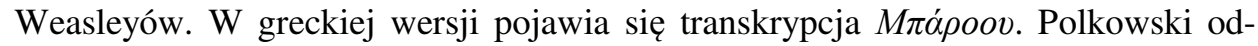
niósł się do dosłownego tłumaczenia angielskiej nazwy i przerobił ją na Norę.

Podsumowując, ogólne założenia poszczególnych tłumaczy są bardzo podobne. Przekładowi podlegają jedynie nazwy ulic w świecie czarodziejów w przeciwieństwie do nazw ulic mugolskich. W obu przypadkach podjęto też decyzję o nieprzekładaniu nazwy wioski Hogsmeade. Różnica pojawia się tylko w przypadku nazwy domu Weasleyów, która w polskim tłumaczeniu zostaje przełożona, w greckim jedynie transkrybowana.

\subsection{Antroponimy}

Antroponim to nazwa własna osoby lub grupy osób. Można wyróżnić antroponimy zespołowe lub kolektywne, które odnoszą się do osób identyfikujących się z tą samą grupą (zrzeszeniem, stowarzyszeniem, partią polityczną, komisją, zgromadzeniem zakonnym, etc.). Właśnie tego typu nazwom poświęcono niniejszy rozdział. Dla przejrzystszej struktury został wprowadzony podział na nieoficjalne grupy, określenia ze względu na profesje i uzdolnienia oraz oficjalne stowarzyszenia, ugrupowania i kluby.

\subsubsection{Nieoficjalne grupy}

W całości cyklu istotne jest odniesienie się do nazw poszczególnych grup ludzi w czarodziejskim świecie, coś w rodzaju swoistych socjoideonimów. Na czoło wysuwa się określenie ludzi niemagicznych - Muggles. W oryginale nazwa nie jest do końca klarowna - kojarzy się ze słowem mug, które można tłumaczyć jako kubek, kufel, naiwniak, frajer. Po grecku nazwa jest transkrybowana i nie podlega odmianie

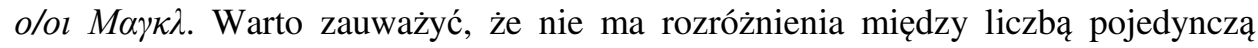


a liczbą mnogą, wszystko zależy od rodzajnika. W języku polskim powstała alternatywna nazwa - mugole. Można założyć, iż tłumacz stwierdził, że nazwa, która odzwierciedlałaby wierniej brzmienie oryginału, czyli magole, fonetycznie kojarzyłaby się polskiemu odbiorcy z magia, czyli z czymś nieprzystającym do natury tych osobników. W wywiadzie (Orliński, 2004) Polkowski zdradził, że:

Ale rzeczywiście, przetłumaczyłem pierwszy tom, używając słowa ,tuman” w miejsce „mugol”. Toczyłem wtedy o to wielkie spory z wydawcą, panem Robertem Gamble. On twierdził, że „muggle” nie ma pejoratywnego znaczenia. Ja na to pokazywałem mu różne słowniki, z których wynika, że to znaczy coś jak „oszołom, głupek”. (...) Z perspektywy czasu muszę jednak przyznać rację mojemu wydawcy. Nadmiernie pejoratywny wydźwięk słowa „tuman” wypaczałby odbiór książki, bo przecież kwestia dobra i zła w „Harrym Potterze” biegnie w poprzek podziału magiczny - niemagiczny. Są źli czarodzieje i dobrzy mugole. W słowie „mugol” zawarta jest nie tyle może obelga, ile łagodne lekceważenie, bo jakoś to słowo się rymuje z lekceważącym określeniem czyjejś narodowości, jak ,Jugol” czy „Angol”.

Wulgarnym przezwiskiem osoby obdarzonej mocą magiczną a wywodzącej się $\mathrm{z}$ rodziny mugolskiej jest w oryginale termin mudblood, który stanowi złożenie słów mud - błoto i blood - krew. Logicznym polskim tłumaczeniem powinno być więc błotokrwisty, co wydaje się jednak długą nazwą w stosunku do zwyczajowych polskich obelg. Polkowski postawił więc po prostu na szlamę. Grecki przekład jest bardziej wierny oryginałowi i wytwarza przymiotnikowe określenie $o \lambda \alpha \sigma \pi o \alpha i \mu \alpha \tau o \varsigma$

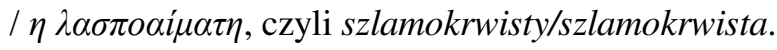

Rozczarowuje nieco fakt, że w greckim tłumaczeniu nie ma równie udanego przekładu nazwy squib określającej nieposiadające mocy osoby urodzone w rodzinach czarodziejów. W oryginale znaczenie terminu jest niezwykle przykre - można je interpretować jako satyrę, paszkwil, stabeusza czy cherlawe dziecko. Grecy transkrybują tę nazwę w postaci $\sigma \kappa o v i ́ \mu \pi$, a Polacy przyjęli określenie charłak, wynikające z cherlawości, którą sugeruje jedno z przywołanych przez tłumacza znaczeń oryginalnego terminu. W założeniu ma to wskazywać słabość pozycji rzeczonego osobnika w magicznym świecie.

$\mathrm{Z}$ trzech omawianych terminów, w języku polskim przełożono dwa z nich i jeden spolszczono, a w języku nowogreckim tylko jedna nazwa uzyskała kreatywny przekład, a dwie pozostałe uległy wyłącznie transkrypcji. Wiadomo jednak, że Polkowski usiłował początkowo przełożyć wszystkie nazwy i tylko interwencja wy-

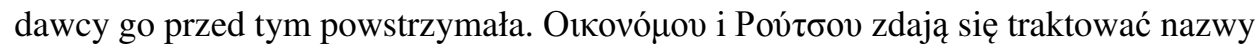
w sposób obojętny, w przeciwieństwie do polskiego tłumacza, który zwraca uwagę na ich domniemany pejoratywny (często wręcz rasistowski) wydźwięk. Tylko w przypadku określenia mudblood twórczyni greckiego przekładu tworzy obraźliwy odpowiednik, jako że jego wulgarnej wymowy nie można w żaden sposób uznać za luźną sugestię. 


\subsubsection{Określenia ze względu na profesje i uzdolnienia}

Kolejną grupę neologizmów tworzą określenia grup czarodziejów ze względu na ich wyjątkowe umiejętności (animagus, metamorphomagus) oraz wykonywaną pracę (auror, snatchers).

Czarodziej zdolny przemieniać się w zwierzę to w oryginale powieści animagus. Nazwa ta składa się ze złożenia dwóch łacińskich wyrazów - animal, czyli zwierzę, i magus, czyli mag. Można zaznaczyć tutaj prawidłowość, która będzie potwierdzana przez kolejne przykłady - w polskim przekładzie zwykle nie tłumaczy się neologizmów mających łacińską lub grecką podstawę, wobec czego neologizm ulega jedynie spolszczeniu i przybiera formę animag. W greckim tłumaczeniu stosunek do łaciny jest zupełnie odwrotny - niemal wszystkie nazwy łacińskie zostają przełożone na grekę. Wobec tego pojawia się ekwiwalent $o \zeta \omega o \mu \alpha ́ x o s$.

Podobną drogę przechodzi w polskim przekładzie słowo metamorphomagus, określające czarodzieja zdolnego zmieniać swój wygląd w zależności od swojej woli. Sama nazwa pochodzi od greckiego metamorphosis - przemiana wraz z końcówką magus - mag. Polkowski nadaje wyrazowi spolszczone brzmienie metamorfomag. Grecy jedynie odrobinę zmienili wyraz, dodając końcówkę -oৎ zamiast

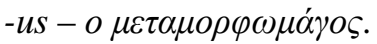

Nie ulega żadnym zmianom w polskim przekładzie nazwa auror, która oznacza czarodzieja wyspecjalizowanego w poszukiwaniu niebezpiecznych kryminalistów. Etymologia neologizmu nie jest do końca jasna, Polkowski podaje kilka możliwości, wszystkie jednak pochodzą z laciny - auris - ucho (jako symbol czujności) lub $\mathrm{Au}$ rora (Eos) - Jutrzenka, ewentualnie aurum - złoto. W greckim tłumaczeniu po raz

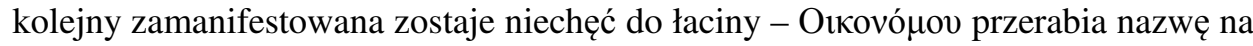

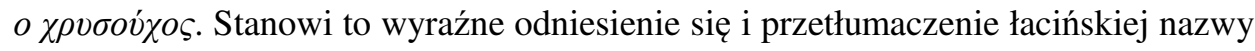

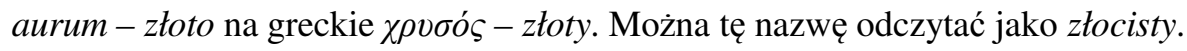

Znacznie mniej chlubne jest określenie snatchers, które odnosi się do czarodziejów trudniących się wyłapywaniem magów pochodzenia mugolskiego za czasów panowania Voldemorta. Oryginalny neologizm można przełożyć dosłownie jako tapacze, ponieważ pochodzi od czasownika to snatch - tapać. W greckim tłumacze-

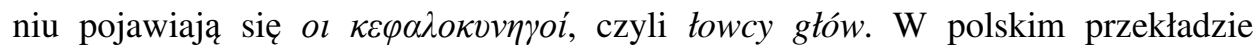
występuje określenie odnoszące się do historii - szmalcownicy. Polkowski (2008: 777-778) wyjaśnia swój wybór w taki sposób:

W czasie II wojny światowej w języku polskim powstało słowo „szmalcownik” oznaczające człowieka, który wydawał Niemcom poszukiwanych przez nich ludzi (zwykle Żydów, ale i członków podziemia walczącego) albo wymuszał na nich okup. Źródłem tego terminu było żargonowe słowo „szmalec”, do dziś oznaczające pieniądze, zwłaszcza w niektórych kręgach mieszkańców podwarszawskich miasteczek. Biorąc pod uwagę podobny kontekst w powieści (reżim zwolenników „,czystości krwi”), termin ten znakomicie oddaje charakter owych „łapaczy”, a przy tym kojarzy się brzmieniowo ze „,szla- 
mami”, a więc ich naturalnymi ofiarami. Na skojarzenie to zwróciła mi uwagę Agnieszka Klunder z Poznania.

Ważną strategią translatorską wyróżniającą się w tym podrozdziale jest założenie Polkowskiego, że nie należy przekładać wyrazów, które mają łacińską lub grecką podstawę. Greckie tłumaczki dosyć konsekwentnie eliminują z przekładu wyrazy o łacińskiej etymologii, przekładając podstawę neologizmu na język grecki.

\subsubsection{Oficjalne stowarzyszenia, ugrupowania, kluby}

W świecie magii występują również grupy o mniejszym lub większym stopniu sformalizowania. Zalicza się do nich zespoły muzyczne (the Weird Sisters), stowarzyszenia (S.P.E.W.), grupy opowiadające się po ,jasnej i ciemnej stronie” magii (the Death Eaters, the Order of Phoenix) czy szkolne kluby (Slug Club).

The Weird Sisters, popularna grupa muzyczna w czarodziejskim świecie, to dosłownie Dziwne Siostry. Polkowski zwraca jednak uwagę, że jednocześnie jest to nazwa nadana przez Szekspira trzem Wiedźmom przepowiadającym Makbetowi przyszłość. Ten argument to zapewne powód odejścia od dosłownego przekładu nazwy i zastąpienie go określeniem Fatalne Jędze nawiązującym do słów fatum i miana nadawanego nieprzyjemnym kobietom. Grecka tłumaczka natomiast oddała

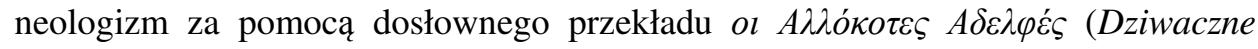
Siostry). Autorowi artykułu nie udało się odnaleźć w dostępnych materiałach i przekładach związku tej nazwy z greckim tłumaczeniem Makbeta Szekspira. Na podstawie zebranych informacji ustalono, że gdyby Oıкovó ski wydźwięk nazwy, to zespół musiałby nazywać się Mojry (ew. Siostry Mojry).

Bardzo ciekawy jest przypadek skrótowca S.P.E.W., czyli organizacji na rzecz skrzatów domowych założonej w czwartym tomie serii przez Hermionę Granger. Jego rozwinięciem jest Society of the Promotion of Elfish Welfare, czyli w wolnym przekładzie Stowarzyszenie Promowania Opieki nad Skrzatami. Pozytywny wydźwięk nazwy neguje jednak fakt, że skrócona wersja przywodzi na myśl czasownik to spew, czyli wymiotować, rzygać. W przekładzie tej nazwy oczywista jest więc konieczność skupienia się na sarkastycznej wymowie skrótowca i stworzenie takiego odpowiednika, który w wersji rozwiniętej będzie brzmiał dumnie, a w skróconej - wywoływał negatywne skojarzenia. W polskim tłumaczeniu pojawia się więc Stowarzyszenie WESZ, czyli Stowarzyszenie Walki o Emancypację Skrzatów Zniewolonych, co wydaje się dosyć chwytliwą opcją. Tłumaczenie Oıovónov znajduje się jednak bliżej oryginału, ponieważ nawiązuje do wydzieliny uznawanej po-

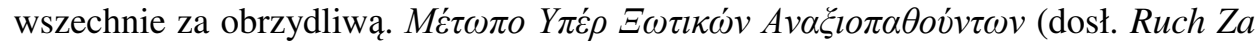

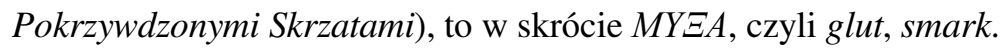

W przypadku ugrupowań w wojnie czarodziejów, czytelnik ma do czynienia $\mathrm{z}$ grupa the Death Eaters, która najprawdopodobniej nie jest formalnym stowarzy- 
szeniem, ale rodzajem samozwańczej formacji dookoła Lorda Voldemorta, oraz $\mathrm{z}$ the Order of Phoenix, która jest co najmniej na poły tajną organizacją skupioną dookoła Albusa Dumbledore'a. Nazwa the Death Eaters ma bez wątpienia za zadanie wywołać pejoratywne skojarzenie, jako że dosłownie oznacza Zjadaczy Śmierci, Żywiacych się Śmierciq. Polski odpowiednik, Śmierciożecy, został zbudowany na podobnej zasadzie jak słowo ludożercy. W języku greckim pojawia się dokładnie

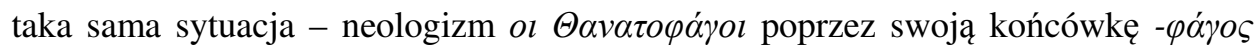
odnosi się do zjadacza czegoś, a w tym wypadku - śmierci (por. $\alpha \nu \theta \rho \omega \pi \circ \varphi \alpha ́ \gamma o \varsigma-$ ludożerca).

The Order of the Phoenix jest wyzwaniem dla tłumaczy z całego świata, ze względu na człon order, który posiada bardzo wiele tłumaczeń. Greckie tłumaczenie

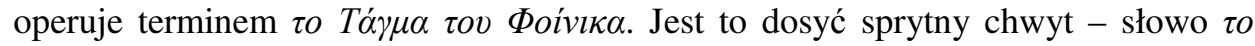

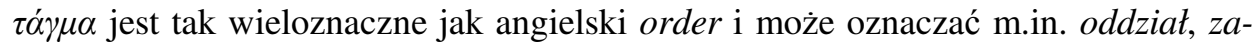
kon, zastęp, gildię. Polkowski (2004: 954-955) za to zdecydował się na nieco kontrowersyjny przekład Zakon Feniksa, co motywuje w poniższy sposób:

ZaKon Feniksa - ang. The Order of the Phoenix. Potteromaniacy wiedzą, że na temat przekładu tej nazwy własnej przetoczyła się w Internecie burzliwa dyskusja. Rzecz w tym, że order (od łac. ordo - „,rząd”, ,,szereg”, „oddział”, „porządek”) ma w języku angielskim wiele znaczeń, najczęściej wykraczających poza dość wąskie znaczenie polskiego słowa „zakon”, czyli stowarzyszenie religijne, które ma swoją regułę i do którego się wstępuje po złożeniu ślubowania i przyjęciu święceń. Zakony rycerskie też miały na ogół charakter religijny, choć zwykle nie sakralny. Te wszystkie cechy zakonu nie bardzo odpowiadają charakterowi tajnej grupy stworzonej przez Albusa Dumbledore'a do walki z Voldemortem, złożonej z czarodziejów i czarownic, w tym osób o nieco wątpliwej moralności (Mundungus czy Snape), wyglądających dość dziwacznie (Tonks), lub przesadnie dbających o bezpieczeństwo swoich dzieci (pani Weasley). Najlepiej oddawałby charakter tej grupy polski termin „tajne stowarzyszenie”, niestety zbyt rozwlekły, zwłaszcza w tytule książki, lub „,bractwo”, czyli związek ludzi skupionych wokół jakiejś sprawy (zawód, idea, wspólne zainteresowania). Wydawca, korzystając z przysługującego mu prawa, zadecydował jednak, że będzie to „Zakon Feniksa”. A w końcu Dumbledore jest tak niezwykłą postacią i żyje w tak niezwykłym świecie, że jego pojęcie ,zakonu" może się bardzo różnić od naszego...

Nazwa Slug Club (dosł. Klub Ślimaka, Ślimaczy Klub) również stanowi duże wyzwanie. Odnosi się do modnych amerykańskich klubów uczniowskich lub studenckich i nawiązuje do nazwiska jej twórcy, Horacego Slughorna. Polkowski przetłumaczył ją jako Klub Ślimaka, co może być niejasne dla czytelnika nieznającego języka angielskiego (nazwisko profesora składa się ze słów slug - ślimak morski oraz horn - róg, rożek). Autorka greckiego tłumaczenia postawiła na transliterację części nazwy tworząc $\eta \Lambda \varepsilon ́ \sigma \chi \eta ~ \Sigma \lambda \alpha \gamma \kappa$ (Klub Slug), co nie oddaje dosyć nieprzyjemnego charakteru organizacji (ślimak pokryty śluzem wydaje się być metaforą śli- 
skich manier Slughorna i oślizgłych „lizusów”, którzy chcieliby należeć do elitarnej grupy najlepiej rokujących uczniów).

W przypadku niemal wszystkich powyższych przykładów, twórcy obu tłumaczeń odnaleźli kreatywne odpowiedniki nazw poszczególnych ugrupowań. Jedyną znaczącą różnicą jest podejście do Slug Club opierającego się na nieprzetłumaczalnej grze słów i wywołaniu określonego skojarzenia. W obliczu takiego wyzwania, polski tłumacz postawił na dosłowny przekład, a autorka greckiego przekładu ratowała się często wykorzystywaną taktyką transkrypcji.

\subsection{Bionimy}

Bionimy to nazwy własne ożywionych obiektów. Należą do nich antroponimy, nazwy zwierząt i fitonimy. Antroponimy zostały już wcześniej omówione, w tej sekcji zamieszczono więc neologizmy określające gatunki flory i fauny występującej w uniwersum Harry'ego Pottera.

\subsubsection{Gatunki zwierząt}

Warto zwrócić uwagę, że począwszy od trzeciego tomu, do słowniczka Polkowskiego wdziera się coraz więcej nazw magicznych stworzeń. Ma to bezpośredni związek z wprowadzeniem do zawartego w powieści programu nauczania wykładanej przez Hagrida lekcji opieki nad magicznymi stworzeniami oraz przejęciu obrony przed czarną magią przez Remusa Lupina. Część z nazw magicznych stworzeń oczywiście istnieje w kolektywnej świadomości od długiego czasu - np. hipogryfy, trytony, wile. Nie zostaną one omówione. Pojawiają się jednak również zupełnie nowe typy stworzeń - boggarts, dementors, gryndilows, flobberworms, nifflers, blast-ended screwts, doxys, bowtruckles, knarls, nogtails. Istnieje też grupa bardziej problematyczna, czyli stworzenia, które istnieją tylko w bardzo ograniczonym folklorze (przykładem mogą tu być np. leprechauns, które, choć znane w tradycji irlandzkiej, nie mają swojego odpowiednika w języku polskim i greckim), zawężenie znanej kategorii poprzez wprowadzenie w niej podgatunków (samo słowo smok nie stanowi neologizmu, ale stworzone przez Rowling nazwy gatunkowe, takie jak Hungarian Horntail, Common Welsh Green, Swedish Short-Snout, Chinese Fireball - już tak) czy opisanie stworzeń legendarnych lub wręcz nieistniejących nawet w świecie czarów (Grim, Crumple-Horned Snorkack, Blibbering Humdinger, wrackspurts).

Neologizm określający upiora zdolnego przybrać postać największego lęku swojego przeciwnika, boggart, nie ma do końca jasnej podstawy czy widocznego źródła inspiracji. Polkowski zwraca uwagę na człon bog, który według niego odnosi się do 
języka słowiańskiego i oznacza $d u c h a^{5}$. Uzasadniona jest więc decyzja Polkowskiego o zachowaniu rzeczonego elementu i o nadaniu nazwie słowiańskiego brzmienia jak w przypadku słów boginka, boginiak. W ten sposób powstał bogin. Oıкovóuov nie podejmuje rękawicy i transkrybuje angielską nazwę jako $\tau o ~ \mu \pi o ́ \gamma \kappa \alpha \rho \tau$.

Nazwa innych przerażających upiorów występujących w trzecim tomie, dementors, ma związek z angielskim słowem demented, czyli obłakany, które pochodzi od łacińskiego demens. Jak zostało to wcześniej zaznaczone, w polskim przekładzie zwykle nie tłumaczy się neologizmów mających łacińską lub grecką podstawę, wobec czego pojawiają się dementorzy. Jest to dosyć mylące, jako że budzi skojarzenie $\mathrm{z}$ dementowaniem lub demencja. Grecki przekład jeszcze bardziej wprowadza odbiorcę w błąd zamieniając źródłosłów łaciński na grecki - straszą w nim

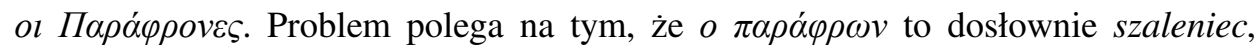
co kłóci się z założeniem książkowym - potwory te miały doprowadzać do obłędu innych, a nie same być obłąkane.

Jeśli zaś chodzi o neologizm gryndilow, to polski tłumacz doszukuje się w nim fonetycznego nawiązania do czasownika to grind - zemleć, kruszyć, co oddaje za pomocą druzgotania w neologizmie druzgotek. Jest to jak najbardziej zrozumiała taktyka, ze względu na wygląd upiora - Lupin wyjaśnia Harry’emu, że długie i silne palce stworzenia są tak naprawdę bardzo kruche i stanowią jego słaby punkt. Autor-

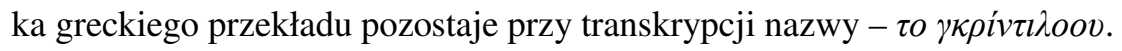

Nazwa flobberworms nie jest już tak jednoznaczna. Oczywisty jest element worm, czyli robak. Flobber nie występuje raczej w tradycyjnych słownikach, jednak według portalu Urban Dictionary określa m.in. gruba leniwa osobę lub brak erekcji. Brzmieniowo kojarzy się też z flubber, czyli tytułową gumowatą substancją z filmu z Robinem Williamsem. Nie jest do końca zrozumiałe, dlaczego Grecy nazywają te stworzenia $\tau \alpha \imath \tau \tau \dot{\alpha} \mu \varepsilon v \alpha \sigma \kappa o v \lambda \eta \dot{\kappa} \kappa \iota$, czyli latajace robale. Po polsku nazwa jest równie enigmatyczna, ale zdecydowanie bardziej kreatywna - gumochtony. Wydaje się, że wykorzystano w niej gumowate skojarzenie i próbowano połączyć żarłoczność z możliwością zmiany kształtu - co sugeruje zastosowanie czasownika chłonać.

Do techniki transkrybowania Grecy wracają w przypadku neologizmu niffler, który zapisują jako $\tau o / \tau \alpha$ ví $\varphi \lambda \varepsilon \rho$. Podstawą bionimu zdaje się być czasownik to sniff, czyli wąchać - teorię popiera fakt, że te sympatyczne zwierzątka za pomocą ryjka wykrywają pokłady złota. $\mathrm{W}$ polskiej wersji przełożono nazwę na niuchacz.

Zdecydowanie mniej przyjaznymi od niuchaczy stworzeniami są Blast-Ended Skrewts. Ich naturę odzwierciedla już sama budowa neologizmu: blast-ended to dosłownie tylnowybuchowy; człon skrewt zaś kojarzy się z wulgaryzmem to screw (pieprzyć, pierdolić). Jest to bardzo wymowny zabieg, ponieważ seria Harry Potter

\footnotetext{
${ }^{5}$ Co ciekawe, nie ma ani słowa na temat możliwości pokrewieństwa terminu z bogeyman, upiorem pozbawionym ściśle zdefiniowanego wyglądu i wyposażanego w określone cechy zależnie od potrzeby (np. mógł być uzbrojony w nożyczki, jeśli niegrzeczne dziecko ssie kciuk).
} 
raczej nie operuje tego typu słownictwem. Polski przekład imituje angielski neologizm. Stwory są, tak jak w oryginale, tylnowybuchowe, drugi element nazwy opiera się najwyraźniej na pochodnej wyrazu przekleństwo (w założeniu, że można je sklać). W sumie powstała nazwa tylnowybuchowe sklatki. Grecka tłumaczka pode-

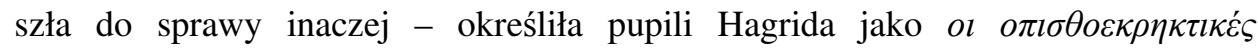

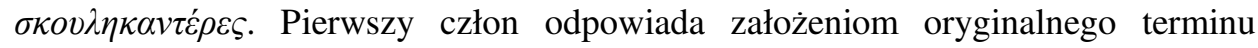
i można go oddać za pomocą słowa tylnoeksplodujacy. Problematyczny jest jednak

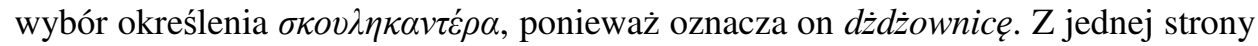
pomaga to $\mathrm{w}$ wizualizacji stworzenia, które nie ma wyraźnie zarysowanej głowy i którego przód i tył trudno od siebie odróżnić. Z drugiej strony, skojarzenie to psuje nieco fakt, że dżdżownica nie należy do szczególnie groźnych i agresywnych zwierząt, a także czytelnik może je mylić ze wspomnianymi już flobberworms, które również przybierają ,robakowatą” formę, ale są o wiele mniej agresywne.

Nowym wyzwaniem dla thumacza jest przetłumaczenie neologizmu doxys. Samo słowo doxy oznacza nierzadnicę, rozpustnice, jednakże w powieści Rowling przyjmuje inną formę w liczbie mnogiej niż wspomniany rzeczownik - doxys zamiast doxies. $\mathrm{W}$ przypadku tak trudnego do przełożenia bionimu, thumacze obu wersji stanęli na wysokości zadania. Polska nazwa bahanki została odnaleziona przez Joannę Lipińską i ma nawiązywać do bachanalii. W założeniu Polkowskiego stworzenia te ma cechować skłonność do nieokiełznanych zabaw, podczas których niszczą wszystko, co popadnie. Grecki przekład jest równie udany - ol $\sigma o v \sigma o v \rho \alpha ́ \delta \varepsilon \varsigma . ~ N a$

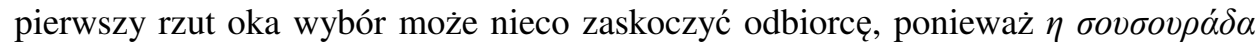
oznacza pliszkę. Termin ma jednak też drugie znaczenie - kokietka, figlarka. Ponad-

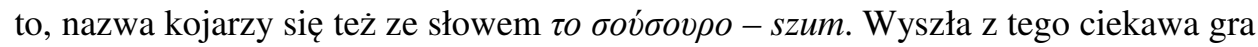
słów - z jednej strony czytelnik ma do czynienia z niewinnymi pliszkami, z drugiej - z już nie tak niewinnymi dziewczętami. Ujęto także odgłos bzyczenia stworzonek. Niełatwo odnaleźć właściwy odpowiednik w języku polskim, ale można grecki termin roboczo przełożyć na trzpiotki.

Angielski neologizm bowtruckle opiera się na połączeniu słów bow - tuk, ukłon oraz truckle - ponizyć się. Jednocześnie zachowane pozostaje fonetyczne podobieństwo do bough - gałazka, co powoduje, że gra słów jest nieprzetłumaczalna. Polski tłumacz odniósł się raczej do „kornej” natury stworzonka nazywając je nieśmiat-

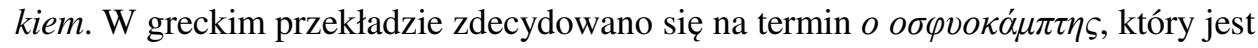
synonimem wyrazu $\delta o v \lambda \circ \pi \rho \varepsilon \pi \eta ́ \varsigma$, co można przełożyć jako służalczy, niewolniczy. Być może chodzi tu o fakt, że te stworzonka są oddanymi strażnikami drzew.

Knarl oznacza po angielsku sęk, należy jeszcze pamiętać, że knar to narośl. W polskim przekładzie przechrzczono to zwierzątko na spiczaka, co zapewne ma wywoływać skojarzenie z jeżem, do którego ma być łudząco podobny. Po grecku neologizm transkrybowano $-\tau o / \tau \alpha \kappa v \alpha \rho \lambda$.

Nogtails to dosyć oczywiste złożenie słów nog - kołek oraz tail - ogon. Polski przekład pozostaje bardzo blisko oryginalnej wersji - kotkogonki. Grecka tłumaczka

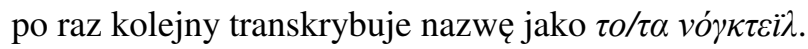


Słowo leprechaun pochodzi od staroirlandzkiego luchorpan, opierającego się na $l u$ - mały oraz corp - ciało. Polkowski starał się zachować podobieństwo fonetyczne do oryginału, jednak nie odmówił sobie dodania końcówki -us, żeby zasugerować niewielkie wymiary istoty (konus). W ten sposób stworzono leprokonusy. W greckiej wersji książki zastosowano dosyć nietypową nazwę $\tau \alpha \xi \tilde{\xi} \omega \tau \iota k \alpha ́$ vóvor. Jej dziwaczność polega na tym, że $\tau \alpha \xi \omega \tau \imath \kappa \alpha ́$ to elfy lub skrzaty (ten sam człon jest wyko-

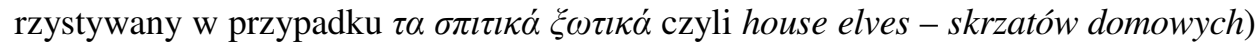
a ol vóvor to krasnoludki, karty. Grecki leprechaun to w takim razie najwyraźniej hybryda skrzata i krasnoludka (skrzatoludek?).

Następne w kolejności są rasy smoków pojawiające się w powieści. Wszystkie są dosyć dosłownie przetłumaczone w obu językach. Hungarian Horntail (złożenie słów horn - róg, tail - ogon) to po polsku rogogon wegierski, a po grecku

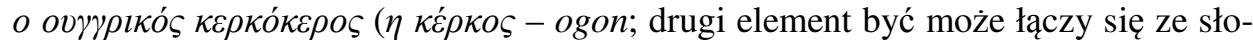

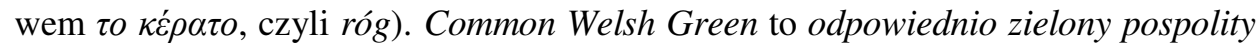

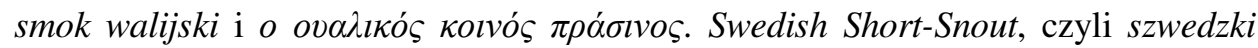
krótkopyski zostaje w języku greckim przekształcony w szerokopystnego -

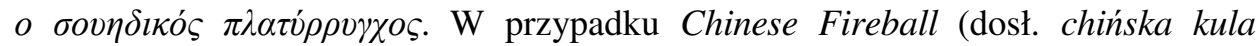

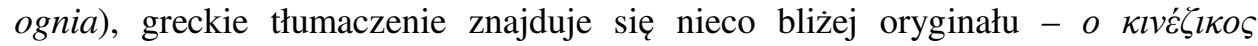

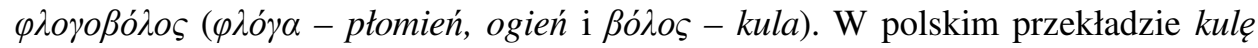
zmieniono na miotanie, czego rezultatem jest chiński ogniomiot.

Neologizm Grim, bardziej niż do gatunku zwierzęcia, odnosi się do nazwy legendarnego omenu. Po angielsku grim to po prostu ponury - co ciekawe, epitet ten jest często zestawiany z rzeczownikiem reaper, co tłumaczy się po polsku jako Ponury Żniwiarz. W polskim przekładzie zamieniono przymiotnik na utworzony na

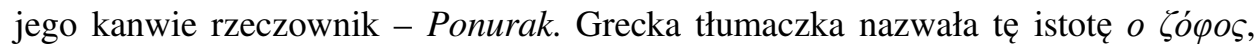
co w języku ludowym oznacza mrok, ciemnicę.

Analizie poddano też nazwy nieistniejących nawet w magicznej rzeczywistości zwierząt, w które uparcie wierzy Luna Lovegood: Crumple-Horned Snorkack, Blibbering Humdinger i wrackspurt. Pierwszy neologizm zawiera w sobie cząstkę Crumple-Horned, co dosłownie oddaje epitet krętorogi i pochodną czasownika to snore, czyli chrapać. Polski przekład jest niemal identyczny - chrapak krętorogi. Warto zauważyć, że w języku polskim przymiotnik i rzeczownik zamieniono miejscami (widać to było również w przypadku np. rogogona wegierskiego). Taka inwersja jest typowa dla wielu gatunków zwierząt występujących w rzeczywistości (por. owczarek niemiecki, lis rudy, perkoz dwuczuby). Dosyć osobliwie, po grecku z chra-

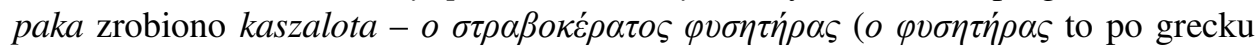

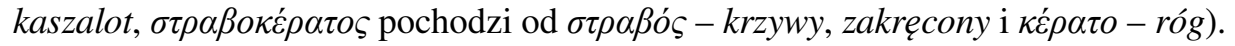

Druga z nazw, Blibbering Humdinger, składa się z określenia humdinger - coś niezwykłego, kapitalnego oraz słowa blibbering, które zdaje się tworzyć skrzyżowanie blabbering i gibbering - oba terminy oznaczają gadanie głupstw. W wolnym tłumaczeniu jest to więc głupiogadajacy niepospolitek, co polski thumacz z powodzeniem oddał za pomocą terminu ględatek niepospolity. Istotnym wydaje się za- 
miana epitetu $\mathrm{z}$ rzeczownikiem podstawowym $\mathrm{w}$ stosunku do oryginału - $\mathrm{w}$ ten sposób nazwa imituje typowe polskie nazewnictwo (por. sroka pospolita, lipień pospolity, grabarz pospolity). Grecki odpowiednik ględatka to natomiast o pivos

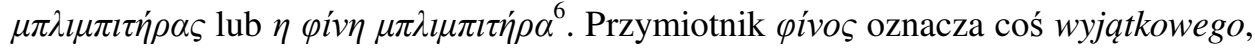
delikatnego, wspaniatego, wyrafinowanego, natomiast pierwszy człon rzeczownika $(\mu \pi \lambda \mu \pi-)$ zapewne ma odnosić się do oryginalnego neologizmu.

Ostatni termin, wrackspurt, stanowi złożenie czasownika to wrack - zadręczać się, gnębić oraz rzeczownika spurt - wytrytsk, przyptyw. Polski odpowiednik jest więc bardzo dosłownym przekładem - gnębiwtrysk. Grecka wersja nazwy wydaje się natomiast niezwykle enigmatyczna - $о$

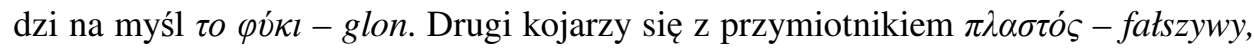
podrobiony, zmyślony. Pozostaje pytanie: dlaczego przypływ złego humoru miałby się nazywać glonopodróbą?

Ogólnie rzecz biorąc, w przekładzie nazw zwierząt nie można wyróżnić jednej spójnej taktyki translatorskiej. Grecki przekład dosyć często rozczarowuje nadmiernym uproszczeniem i brakiem inwencji translatorskiej, czyli przetranskrybowaniem oryginalnego neologizmu (np. $\tau o / \tau \alpha$ vó $\gamma \kappa \tau \varepsilon i ̈ \lambda, \tau o / \tau \alpha$ ví $\varphi \lambda \varepsilon \rho$ ), a wybory tłumacza są

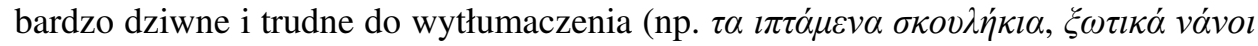
czy $\tau$

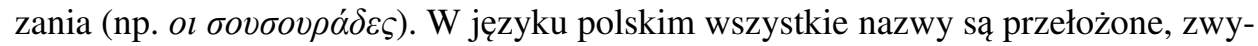
kle w bardzo odkrywczy i nowatorski sposób. Ważne są zabiegi mające na celu naśladowanie naukowych nazw bionimów (por. chrapak krętorogi, rogogon węgier$s k i$, ględatek niepospolity), które można uznać za rodzaj charakterystycznego dla literatury science-fiction pseudonaukowienia tekstu poprzez pseudoterminologizacje (Chomik i Krajewska, 2011: 15).

\subsubsection{Fitonimy}

Poza nietypowymi gatunkami zwierząt, uczniowie Hogwartu mają do czynienia z magicznymi roślinami, które nie występują w świecie mugoli. W określonym materiale badawczym pojawiają następujące fitonimy: Whoomping Willow, Bubotuber, Gillyweed i Snargaluffs. W niniejszym podrozdziale omówiony zostanie również termin stinksap, który stanowi bezpośrednią pochodną magicznej rośliny.

Neologizm Whoomping Willow jest dosyć prostym i obrazowym tworem językowym - czasownik to whomp oznacza grzmotnać, przywalić, a willow to po prostu wierzba. W języku polskim powstał analogiczny termin wierzba bijaca, w grece -

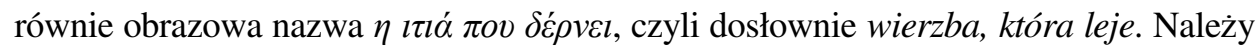
tutaj zwrócić uwagę na wspomnianą już wcześniej zasadę, że terminy posiadające cząstkę -ing w polskim przekładzie oddane są za pomocą konstrukcji ,imiesłów przy-

\footnotetext{
${ }^{6}$ Nie można określić rodzaju, termin pojawia się jedynie w liczbie mnogiej.
} 
miotnikowy + rzeczownik”, w greckim figurują natomiast jako „rzeczownik + zaimek przymiotny + czasownik".

Słowo Bubotuber zyskuje w oryginale niezbyt apetyczny wydźwięk dzięki wykorzystaniu łacińskiego terminu bubo, oznaczającego dymienicę (choroba powodująca obrzęk przepukliny) oraz słowa tuber, które może oznaczać zarówno bulwe jak i guz (w znaczeniu medycznym). Pomimo, że Polkowski zwykle unika przekładu neologizmów z łacińskim rdzeniem, to w tym wypadku czyni wyjątek i przemianowuje roślinę na czyrakobulwę. Można to tłumaczyć chęcią stworzenia dobitnego wyobrażenia na temat wyglądu tego osobliwego okazu flory. Język grecki operuje

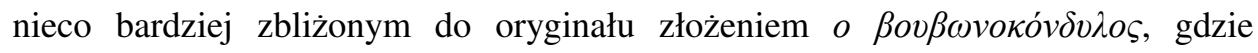

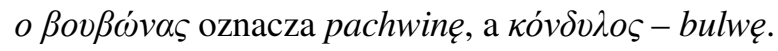

Gillyweed, ze względu na swoją łopatologiczną budowę (złożenie słów gilly skrzela i weed - ziele), nie sprawia żadnych trudności w przekładzie. Zarówno $\mathrm{w}$ języku polskim jak i w greckim pojawia się dosłowna analogia - skrzeloziele oraz

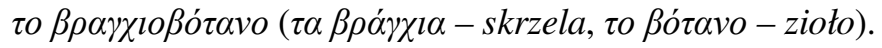

Nieco bardziej wyrafinowanym przykładem neologizmu są snargaluffs. Snare jako rzeczownik może oznaczać pułapkę, sidta, wnyki, a jako czasownik ma znaczenie usidlić; końcówka -galuff kojarzy się fonetycznie z galumph czyli toczyć się, niezdarnie podskakiwać i z galop - galop. Pojawia się również skojarzenie ze słowem snag, które oznacza m.in. podwodny korzeń lub pień. I chyba właśnie tą asocjacją zasugerowali się twórcy omawianych tłumaczeń. Po polsku neologizm oddano za pomocą terminu wnykopieńki - połączenia wnyków i pni. Oıкovópov

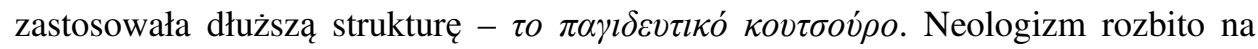
dwa wyrazy, z których jeden odnosi się do przymiotnika utworzonego od rzeczow-

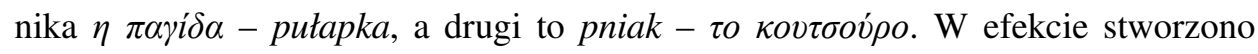
nieco kuriozalne określenie podstępne pniaki.

Stinksap jest bardzo prostym połączeniem słów stink - smród, śmierdzieć oraz sap - soki roślinne. Po polsku powstała analogiczna wersja odorsok (odór + sok), w grec-

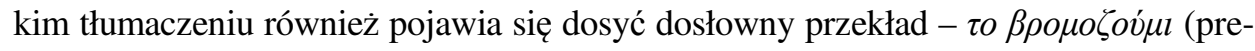

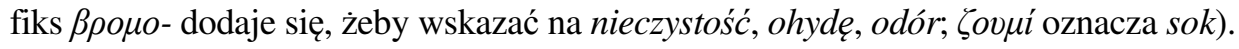

Omawiając tłumaczenia neologizmów-fitonimów można zauważyć wspólną tendencję tłumaczy do tworzenia kreatywnego przekładu nazw. Grecka tłumaczka ma skłonność do tworzenia niekiedy dłuższych terminów w porównaniu do polskie-

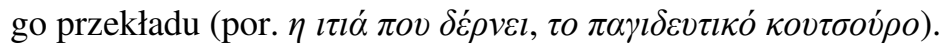

\subsection{Chrematonimy}

Chrematonimy to bardzo bogata kategoria onomastyczna, do której należą wszelkie nazwy własne obiektów materialnych i niematerialnych, wytworzonych jako efekt kulturowej działalności człowieka. Oznacza to, że do chrematonimów 
zaliczają się nazwy produktów, usług, firm, organizacji, przedsięwzięć społecznych, wytworów lub wydarzeń artystycznych itd. W trosce o przejrzystość zestawienia, neologizmy należące do tej kategorii pogrupowano (dosyć instynktownie) w następujące podtypy: artefakty, firmonimy, gry i pojęcia związane ze sportem, dziedziny wiedzy oraz czary i eliksiry.

\subsubsection{Artefakty}

Do pierwszego podtypu kategorii, do artefaktów, zaliczono przedmioty, które zdają się być w jakiś sposób unikalne i wyjątkowe w świecie czarów. Z materiału badawczego wyróżniono cztery takie obiekty - Marauders Map, Pensieve, the Deathly Hallows i the Elder Wand.

Marauders Map, magiczna mapa terenów szkolnych wykonana przez Remusa Lupina, Jamesa Pottera, Syriusza Blacka i Petera Pettigrew, zyskała swoją nazwę od mało popularnego już w angielszczyźnie słowa pochodzenia francuskiego marauder. Jak wyjaśnia w swoim słowniczku Polkowski (2001: 454), słowo to oznacza wtóczęgę, który tylko patrzy gdzie by tu coś zwędzić. Chcąc zachować brzmienie oryginału, należałoby przetłumaczyć tę nazwę na Mapę Maruderów. Polski tłumacz uznał jednak, że maruder zbytnio kojarzyłby się z ociaganiem, marudzeniem, wobec czego zastąpił to słowo huncwotem - również pochodzącym z języka obcego (w tym wypadku z niemieckiego), które obecnie brzmi już w sposób nieco archaiczny. Na tej podstawie pojawiła się Mapa Huncwotów. Grecka tłumaczka skorzystała z zu-

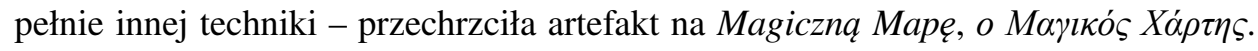
Jest to jedna z częściej używanych przez nią taktyk translatorskich - zamiast stworzyć analogiczny przekład, Oıкovó przed nazwą obiektu. Technika ta ma dosyć dużą wadę - jeśli dany przedmiot należy do świata magii, to dosyć oczywiste, że jest magiczny i powtarzanie tego faktu w nazwie jest redundantne.

Nie wiadomo tak naprawdę, w jakim stopniu unikalnym obiektem jest Pensieve. Są podstawy, żeby uznać przedmiot za artefakt - w serii występuje tylko jeden taki przyrząa, przechodzący w dodatku z rąk do rąk. Co więcej, wiadomo że należy do Albusa Dumbledore'a, który jest twórcą i posiadaczem wielu rzadkich instrumentów. Samo słowo posiada element pensive, czyli zamyślony (łac. penso - rozważać, rozmyślać) oraz cząstkę sieve - sito. Polski tłumacz odstąpił od taktyki nieprzekładania rdzenia łacińskiego zapewne żeby ułatwić czytelnikowi wyobrażenie na temat obiektu. Stworzył neologizm Myślodsiewnia, co jest oczywistym połączeniem słów myśl i odsiewać. Oıкovó $\mu$ ov rozbiła po raz kolejny krótki neologizm na kilka wyra-

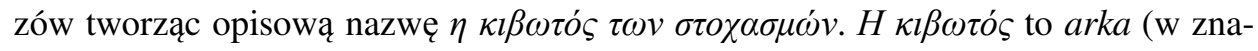

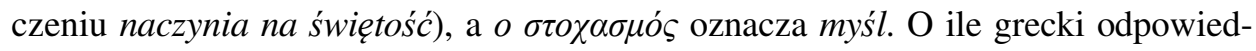
nik nie wydaje się być tak chwytliwy jak oryginalny neologizm i jego polska 
wariacja, to dosyć przemyślane i stylowe jest wykorzystanie słowa o znaczeniu religijnym (por. the Order of the Phoenix, the Deathly Hallows).

Występujące w tytule ostatniego tomu sformułowanie the Deathly Hallows spędzało ponoć tłumaczom sen z powiek. Żeby zrozumieć sedno problemu, należy najpierw omówić znaczenie poszczególnych składowych oryginalnego neologizmu. Deathly to epitet opisujący obiekty grobowe, trupie, należace do śmierci; hallow to natomiast ktoś lub coś świętego (np. święci, miejsca święte, relikwie świętych). Ponadto, hallow kojarzy się też z greckim i łacińskim halos, czyli z aureolą. Ogólnie rzecz biorąc, dosyć dosłownym tłumaczeniem byłyby Świętości Śmierci, co nie jest jednak zbyt chwytliwą nazwą. Polkowski (2008: 776-777) przedstawił różne sposoby przekładu tej nazwy w kilku językach:

Większość tłumaczy, nie zważając na treść książki, przełożyła tytuł prawie dosłownie jako „Relikwie Śmierci” (tak jest w przekładzie ukraińskim i francuskim, natomiast w niemieckim użyto bardziej pojemnego i bliskiego oryginałowi słowa Heiligtümer, które oznacza „relikwie” ale i ,świętości”), tłumaczka izraelska wybrała „Skarby Śmierci”, norweska „Talizmany Śmierci”, są też po prostu „Dary Śmierci” (np. w przekładzie włoskim i rosyjskim).

Sam Polkowski zdecydował się na Insygnia Śmierci, ponieważ uznał tytułowe obiekty za symbole władzy nad śmiercią. Co więcej, różdżka, kamień i pelerynaniewidka zdają się doskonale korespondować ze zwyczajowymi insygniami władzy królewskiej - berłem, jabłkiem i płaszczem. Greckie tłumaczenie operuje natomiast

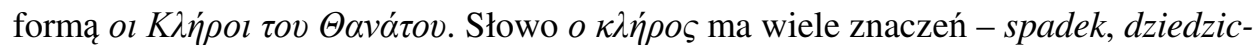
two, los, udziat, kler. Nazwę można więc przetłumaczyć jako dziedzictwo albo spadek śmierci - warto zwrócić tutaj uwagę, że w języku greckim występuje liczba mnoga, której nie oddaje dosłowne polskie tłumaczenie (Spadki Śmierci).

Jedynym szerzej opisanym w słowniczku Insygnium Śmierci jest the Elder Wand. Należy zauważyć, że słowo elder ma dwa różne znaczenia - starszy oraz dziki bez. Polkowski uznał, że Dzikobzowa Różdżka lub Starsza Róż̇̇ka brzmiałyby po prostu źle, więc pozwolił sobie na odejście od dosłownego tłumaczenia i odniósł się do koloru bzu i złowrogiej magii - do czerni. Dlatego też polski czytelnik ma do czynienia z Czarnq Różdżką. Oıкovó $\mu$ ov natomiast po raz kolejny konstruuje wielo-

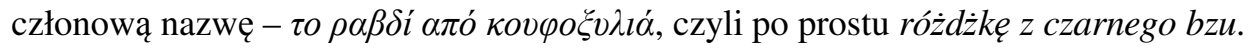

W przypadku wszystkich omówionych artefaktów twórcy opisywanych przekładów stworzyli kreatywne odpowiedniki nazw. Polski translator pozwala sobie często na dosyć luźną inspirację oryginalnymi terminami, starannie przystosowując określenia do specyfiki polskiego języka i do budowania określonych wrażeń. W przypadku greckiej tłumaczki nie udaje się wyodrębnić jednej konsekwentnej taktyki,

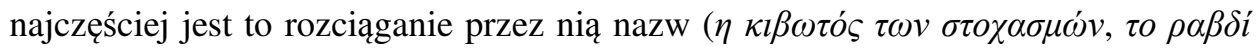

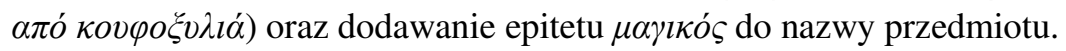




\subsubsection{Firmonimy}

Firmonimy to dosyć szeroka grupa wyrazów określających nazwy handlowe nadawane firmom i produktom. W uniwersum powieści pojawia się cała gama magicznych marek i towarów, do których zaliczają się: proszek komunikacji Floo Powder, kurs czarów dla charłaków Kwikspell, autobus czarodziejów the Knight Bus, miotła Firebolt, wykrywacz podstępów sneakoscope, śmierdząca petarda dungbomb, cukiernia Honeydukes, niskoalkoholowy napój butterbeer, cukierek-pułapka Ton-tongue Toffi, magiczne lornetki Omnioculars, zestawy cukierków umożliwiających symulowanie choroby Skiving Snackboxes (w tym: Puking Pastiles, Fainting Fancies, Noseblood Nougat), czasopismo The Quibbler oraz środek wywołujący zatwardzenie $U-N O-P O O$.

Pierwszy z firmonimów to Floo Powder. Można uznać, że Floo odnosi się do fonetycznego odpowiednika słowa flue oznaczającego przewód (np. kominkowy). Polskie thumaczenie jest onomatopeiczne - proszek Fiuu najprawdopodobniej sugeruje świst wskazujący na szybkość poruszania się jego użytkowników. Oıкovónov

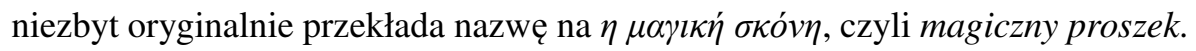

Jeszcze mniej ciekawa jest taktyka zastosowana przy tłumaczeniu na język nowogrecki przyspieszonego kursu czarów Kwikspell. Oıкovó $\mu$ ov jedynie transkrybuje słowo ( tywny przekład Wmigurok, oparty na angielskim złożeniu, które sugeruje szybką naukę czarów (quick spell).

W przypadku the Knight Bus, słowo knight, czyli rycerz, brzmi identycznie jak night, czyli noc. Autor polskiego przekładu umotywował dosyć radykalne odejście od dosłownego przekładu w taki sposób: Uznałem, że charakter tego magicznego pojazdu, który zjawia się, gdy go wezwiemy, bardziej uzasadnia polska nazwe „Btędny Rycerz” niż np. „Nocny Rycerz” albo jeszcze dziwaczniejszy „,Rycerski Autobus" (Polkowski, 2001: 452). Grecka tłumaczka nie wykazała się analogicznym tokiem myślowym, na skutek czego powstała dosyć dziwaczna hybryda $\tau o$

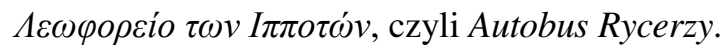

Neologizm Firebolt (dosł. Pocisk Ognia) nie sprawia najwyraźniej większych

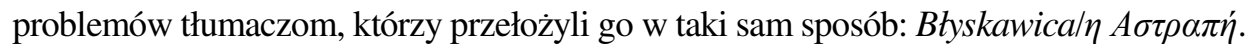

Sneakoscope (od czasownika to sneak - donosić, kablować) zostało po polsku przetłumaczone na fatszoskop (kabloskop byłby widocznie zbyt mętną nazwą), po

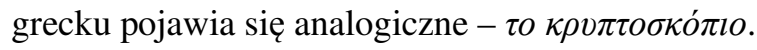

Dungbomb to dosyć oczywiste złożenie słów dung - gnój i bomb - bomba, którego polskim odpowiednikiem jest tajnobomba. Po grecku pojawia się trochę inna

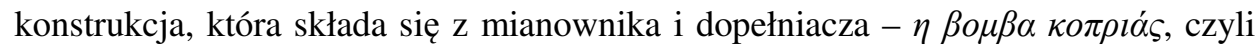
bomba gnoju.

Odnośnie nazwy Honeydukes, to dosłownie należałoby ją oddać za pomocą określenia Książęta Miodu. W polskiej tradycji jednak raczej nie nazywa się miejsca 
na cześć funkcji czy godności danej osoby (raczej trudno odnaleźć lokal gastronomiczny z szyldem Hrabia czy Księżniczka). Prawdopodobnie z tej przyczyny nazwę cukierni przemianowano na Miodowe Królestwo. W greckim przekładzie pojawia

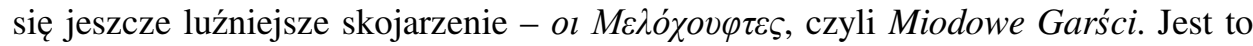
uzasadnione o tyle, że w Grecji, jak i w Polsce, smakołyki zajada się garściami ( $\mu \varepsilon \tau \iota \varsigma \chi о \dot{\varphi} \varphi \tau \varepsilon \varsigma)$.

Popularny napój butterbeer tłumaczy się dosłownie jako maślane piwo, co traf-

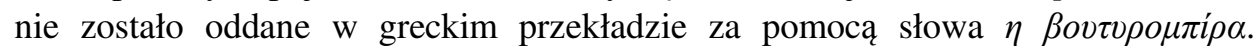
W polskim tłumaczeniu pojawia się rozbieżność - piwo, zamiast maślanego, staje się kremowe.

W przypadku Ton-tongue Toffi, nazwa składa się ze słów ton - tona, tongue język i toffi. W oryginale występuje gra słów opierająca się na powtórzeniu dźwięku ton-ton na początku. W języku polskim nie można było osiągnąć podobnego brzmienia, tak więc usunięto jednostkę wagi i wskazano za to na rozmiar języka. Nazwa została przekształcona w Gigantojęzyczne Toffi. W greckiej wersji język

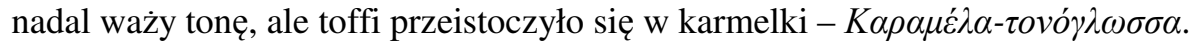

Słowo omnioculars posiada łaciński rdzeń omnis - wszelki oraz końcówkę słowa binoculars - lornetka. Ze względu na element łaciński, Polkowski zastosował jedynie spolszczenie tworząc omnikulary. Grecka tłumaczka udowadnia po raz kolejny

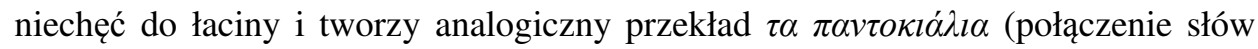
$\pi \dot{\alpha} v \tau \alpha-w s z y s t k o$ i $\gamma v \alpha \lambda \imath \dot{\alpha}-o k u l a r y)$.

Przedmiot pożądania wszystkich mugolskich uczniów, czyli wyprodukowane przez bliźniaków Weasley Skiving Snackboxes, wzięły swoją nazwę od czasownika to skive - migać się, urwać się (z czegoś) oraz snackbox - pudetko z przekaskami. W języku polskim przerobiono je na Bombonierki Lesera (Wagarujace Przekaski nie brzmią przekonująco). Grecki czytelnik ma za to do czynienia z Podstępnymi

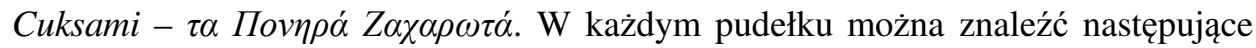
słodycze, których nazwa sugeruje ich sposób działania: Puking Pastiles (Wymiotujace Pastylki), Fainting Fancies (Omdlewajace Fantazje) i Noseblood Nougat (Nosokrwisty Nugat). Metoda tworzenia oryginalnych nazw jest wręcz banalna - chodzi o stworzenie dwuczłonowego określenia składającego się z wyrazów zaczynających się na tę samą literę. Pierwszy z nich określa działanie cukierka, a drugi odnosi się do rodzaju słodyczy. Nie jest jednak możliwe równie przemawiające do wyobraźni odtworzenie nazw w języku polskim. Tłumacz zdecydował się przemianować cukierki odpowiednio na wymiotki pomarańczowe (cukierki są pomarańczowe ze względu na kolor końcówki, którą trzeba zjeść, żeby zacząć wymiotować), omdlejki grylażowe (z nieokreślonych bliżej powodów, tłumaczowi najbardziej z omdlewaniem kojarzyły się czekoladki grylażowe) i krwotoczki truskawkowe (skojarzenie oparte na kolorze). Warto zauważyć, że w języku polskim właściwość pastylek staje się podstawą nazwy, podczas gdy w oryginale sposób działania to jedynie dopełnie-

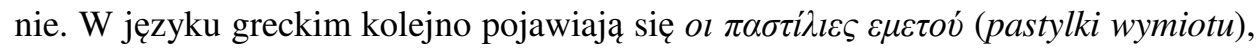




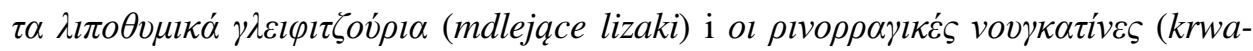
wiqce z nosa cukierki nugatowe). Pojawia się tutaj brak konsekwencji w budowie nazw. Nie jest możliwe również ustalenie na pierwszy rzut oka, dlaczego dany cukierek ma określoną właściwość.

Przykładem bardzo wymownej nazwy jest The Quibbler, czyli tytuł brukowego czasopisma wydawanego przez Ksenofiliusa Lovegooda. Quibbler jest to osoba przesadnie drobiazgowa, czepiająca się szczegótów, formalista; czasownik to quibble oznacza żonglowanie stowami. Ergo - quibbler zyskuje również znaczenie osoby żonglującej słowami, by osiągnąc zamierzony efekt, czyli po prostu matacza, krętacza, blagiera. Polkowski wykazał się zdroworozsądkowym podejściem i uznał, że nikt nie nazwałby swojego czasopisma Blagierem, tak więc sam postanowił przemianować je na Żonglera. Greckie tłumaczenie wydaje się być jeszcze bardziej

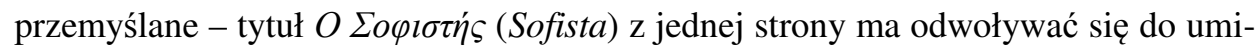

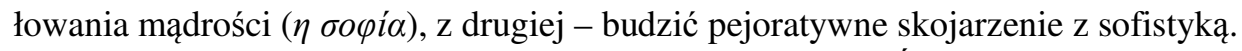

Ostatnia nazwa to prawdziwy koszmar translacyjny. Środek wywołujący zatwardzenie $U-N O-P O O$ ma fonetycznie odwoływać się do słów ty nie srasz. Gra słów zasadza się na podobieństwie brzmieniowym z przydomkiem Voldemorta YouKnow-Who. Polkowski przyznaje, że polski przekład, $Q-P Y B L O K$, był pracą zbiorową, a największe zasługi mają Justyna Frank-Kamińska oraz Marta i Iwona Sznicer. Nie ma dużego podobieństwa fonetycznego, ale prawie rymuje się z Sam-WieszKto. Natomiast $\Xi E P-N A-\Pi O N$, grecki odpowiednik hitu sklepu Freda i George'a, nie jest, jak w oryginale i w wersji polskiej, środkiem wywołującym zatwardzenie, ale wymioty. Pochodzi od czasownika $\xi \varepsilon \rho v \omega ́-$ wymiotować i doskonale przypomina

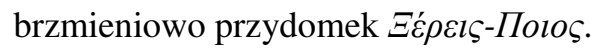

Wszystkie powyższe przekłady wiążą się z zastosowaniem różnorodnych technik translacyjnych, jednakże nie wyłaniają się żadne nowe tendencje przekładu. Od czasu do czasu potwierdzają się wcześniej opisane taktyki (stosunek do łaciny, transkrypcja nazw, konstrukcje neologizmów, wykorzystywanie epitetu $\mu \alpha \gamma \iota \kappa o ́ s)$.

\subsubsection{Gry i pojęcia związane ze sportem}

Wśród gier i dyscyplin sportowych uniwersum Harry'ego Pottera można wyróżnić quiddich i słownictwo z nim bezpośrednio związane (quaffle, bludgers, snitch), grę gobstones oraz międzyszkolne zawody the Triwizard Tournament.

Co do quidditcha (łac. quiddity - sedno sprawy, istota rzeczy, wykręty, wybiegi), to nazwy tej tłumacze nie starają się przełożyć, choć oczywiście jej zapis ulega transkrypcji w greckim przekładzie ( $\tau$ o Koviv $\tau \imath \tau \varsigma$ ). Interesujące jest natomiast indywidualne podejście do nazw piłek. I tak w przypadku quaffle (to quaff-pić coś tapczywie, żłopać) i snitch (snitch - donosiciel, kapuś, człowiek, który lubi zmyślać różne rzeczy), w polskim przekładzie zasugerowano się nie faktycznym znaczeniem, 
a fonetycznym podobieństwem, wskutek czego powstały nazwy kafel i (złoty) znicz. Przy bludgers posłużono się podobnym skojarzeniem jak w podstawie angielskiego neologizmu, czyli słowem bludgeon oznaczającym pałkę, maczugę. W ten sposób powstały tłuczki. W języku greckim nazwy są o wiele bardziej zunifikowane, ale też

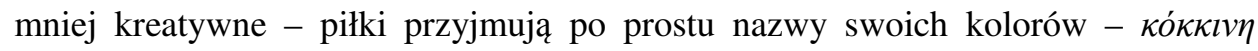

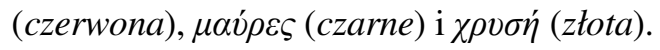

Nazwa gobstones to złożenie słów gob - plwocina oraz stones - kamienie, kamyki. W założeniu ma być to popularna gra, w której pionki plują w przegrywającego gracza obrzydliwym płynem. W polskim przekładzie nazwa przyjęła formę gargulki, ponieważ nawiązuje do gargulca - fantazyjnego rzygacza umieszczanego na budowlach. W greckim tłumaczeniu neologizm ten spowodował wiele nieprawidłowości. W trzecim i czwartym tomie sagi nazwa gry została oddana jako

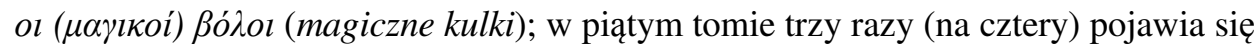

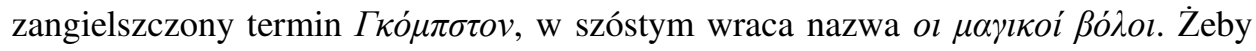
jeszcze bardziej zagmatwać sytuację, w trzecim tomie, na trzy użycia tego neologizmu w oryginale, grecka tłumaczka dwa razy zastąpiła je określeniem na inną grę

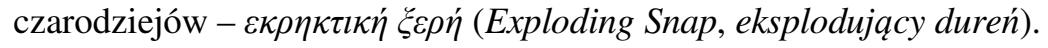

The Triwizard Tournament zawiera w sobie cząstkę tri- wskazującą na potrójność (chodzi zapewne jednocześnie o trzy szkoły biorące udział w rozgrywkach, trzech reprezentantów i trzy zadania konkursowe), słowo wizard oznaczające czarodzieja oraz tournament czyli turniej. W Polsce znaczenie neologizmu oddano za pomocą Turnieju Trójmagicznego, co wydaje się dosyć rozsądnym wyborem trans-

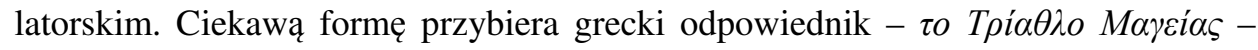
dosłownie należałoby go tłumaczyć jako Magiczny Triatlon. Nie jest to całkowicie bezsensowne rozwiązanie, skoro turniej składa się z trzech dyscyplin/prac ( $\tau \rho i \alpha$ $\alpha \theta \lambda \dot{\eta} \mu \alpha \tau \alpha)$.

W tej subkategorii należy zwrócić szczególną uwagę na różnorodność technik tłumaczenia nazw piłek w quiddichu, jako że w języku polskim pojawiła się nowa taktyka translatorska, jaką jest odwołanie się tłumacza do skojarzenia związanego z brzmieniem oryginalnego wyrazu. W tym wypadku grecki przekład odznacza się większą konsekwencją, jednakże jednocześnie wyróżnia się mniejszą twórczością w kreowaniu odpowiedników.

\subsubsection{Dziedziny wiedzy}

Grupą chrematonimów odnoszących się do kulturowej i intelektualnej działalności człowieka mogą być dziedziny naukowe, a w przypadku uniwersum stworzonego przez Rowling - także rodzaje magii praktykowane przez czarodziejów. W korpusie wyrazów pojawiają się trzy dyscypliny sztuki magicznej, które wymagają omówienia - transmutation, legilimency i occlumency. 
Od razu rzuca się w oczy fakt, że podstawą każdego z wyrazów jest rdzeń łaciński. W przypadku transmutation jest to transmutatio, czyli zamiana, przestawienie (od trans - za, poza, z tamtej strony i mutatio - zmiana). Od razu należy zaznaczyć, że termin transmutation nie został stworzony przez Rowling, ale istniał od dawna w języku angielskim. Można go jednak uznać za neologizm, ponieważ nie pojawiał się dotąd w znaczeniu nadanym przez pisarkę. Legilimency wywodzi się od łac. legere - czytać oraz mens - umyst, myślenie, serce, dusza, wyobrażenia, wspomnienia. Occlumency składa się ze słów occludo - zamknać oraz wspomnianego już mens.

Polkowski, który generalnie przyjął zasadę nietłumaczenia nazw z łacińskim rdzeniem, wszystkie powyższe terminy jedynie spolszczył - transmutacja, legilimencja, oklumencja. Zabieg ten polegał na zamianie końcówek -tion i -ncy na bardziej rozpowszechnione w języku polskim -cja (por. nekromancja, chiromancja, piromancja) oraz na przekształceniu -cc- na - $k$ - w przypadku occlumency.

$\mathrm{W}$ języku nowogreckim wszystkie wspomniane terminy ulegają ogromnej modyfikacji, ze względu na taktykę przekładania łacińskich elementów na grekę. Tak

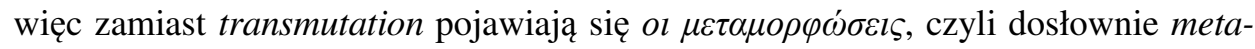
morfozy, przemiany. Legilimency zostaje zastąpiona terminem $\eta \delta \imath \varepsilon \imath \sigma \delta v \tau \imath \kappa \eta$, gdzie

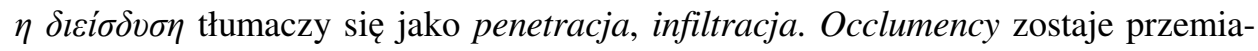
nowana na $\eta \sigma \varphi \rho \alpha \gamma \imath \sigma \mu \alpha \tau \iota \kappa \eta ́$, co ma kojarzyć się ze słowem $\eta \sigma \varphi \rho \alpha \gamma i \delta \alpha-p i e c z e ̨ c ́$ (oklumencja to rodzaj pieczętowania myśli).

Cała sekcja stanowi potwierdzenie wcześniej omówionych taktyk stosowanych wobec wyrazów z łacińską podstawą.

\subsubsection{Czary i eliksiry}

Ostatnia omawiana grupa neologizmów to rodzaj rezultatów magicznej działalności, czyli czary i eliksiry. W całości serii jest nazwana i opisana ich ogromna ilość, jednak ze względu na ograniczenie materiału badawczego w artykule omówione zostaną jedynie pojęcia: Portkey, Horcrux, Inferius, Trace (rezultaty zaklęć), Colloportus, Sectusempra (formuły zaklęć) i Felix Felicis (nazwa eliksiru).

Portkey to złożenie słów port - port, otwór (łac. porto - jechać, przenosić) oraz key - klucz, klawisz. Mimo że Polkowski wspomniał w swoim słowniczku o podobieństwie fonetycznym tego słowa do wyrazu portki, zdecydował się ogłosić konkurs na thumaczenie, który wygrał ostatecznie termin świstoklik. Nawiązuje on do onomatopeicznych wyrazów świst i klik, co zapewne ma obrazować sposób działania zaczarowanego obiektu, przenoszącego użytkownika z niebywałą prędkością w oddalone miejsce. Grecka tłumaczka przy przekładzie nazwy najwyraźniej skorzystała z podobieństwa oryginalnego terminu do słowa portal $-\eta$ Пí̉ $\eta$ oznacza bramę lub $d r z w i$.

Horcrux, jako wyraz potężnej czarnej magii, o której uczniowie Hogwartu nie mają prawa wiedzieć, nosi dosyć zagadkową nazwę. Jego drugi element składowy 
jest dosyć oczywisty - pochodzi od łac. crux oznaczającego krzyż, mękę. Ambiwalentne uczucia może budzić przyrostek hor-, który w łacinie kojarzy się z godzina lub ze zgroza, a ze względu na grekę łączy się z chórem i tańcem. Dociekanie etymologii nie wpłynęło znacząco na polski odpowiednik tego słowa, które, według fabuły powieści, ma przecież być i tak niezrozumiałe dla niewtajemniczonych. Niezależnie, czy podstawą jest łaciński, czy grecki termin, Polkowski nie przekłada nazwy, a jedynie ją spolszcza tworząc horkruks. Oıкovó

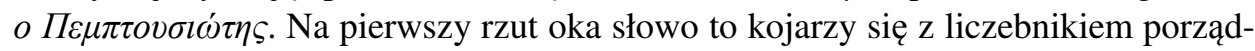
kowym $\pi \dot{\varepsilon} \mu \pi \tau o \varsigma$ - piąty, jednak taka konotacja nie niesie ze sobą większego sensu. Bardziej logiczne jest połączenie nazwy ze słowem $\pi \varepsilon \mu \pi \tau o v \sigma i ́ \alpha-k w i n t e s e n c j a$, esencja. Horkruksy miały zawierać w sobie cząstkę duszy ich stwórcy, tak więc musiały obejmować kwintesencję istoty.

Kolejnym neologizmem naznaczonym dosyć makabryczną asocjacją jest Inferius oznaczający ożywione czarami zwłoki. Określenie pochodzi oczywiście z łaciny, od słowa infernum - piekło. W języku polskim nie występuje żaden przekład

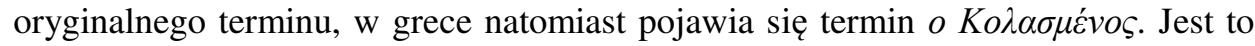
analogiczny przekład oryginalnego neologizmu pochodzący od słowa $\eta \kappa o ́ \lambda \alpha \sigma \eta$, czyli piekło. $\mathrm{W}$ wolnym przekładzie jest to więc piekielnik, potępieniec.

Trace oznacza w języku angielskim ślad, trop. Wg Polkowskiego ślad to jednak coś, co zostawia się po sobie, a celem zaklęcia jest zlokalizowanie (namierzenie) noszącego go czarodzieja. Dlatego też przełożył nazwę jako Namiar. Podobnie jest

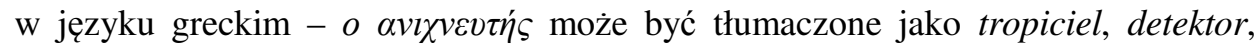
wykrywacz, czujnik.

Colloportus stanowi formułę zaklęcia służącego do zamykania drzwi i okien. Słowo pochodzi od łacińskiego colligo - wiazać, spajać, powstrzymywać oraz porta - drzwi, brama. Po polsku praktycznie wszystkie zaklęcia są nieprzekładane (wyjątkiem jest np. zaklęcia czyszczącego Scourgify - chłoszczyść), tak więc formuła pozostaje taka sama - Colloportus. W greckim przekładzie taktyka jest zupełnie przeciwna - skoro prawie wszystkie zaklęcia mają podstawę łacińską (z małymi

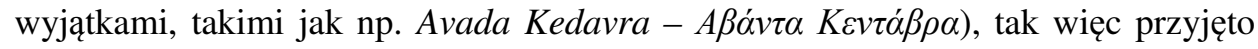
zasadę, że niemal wszystkie formuły czarów przerobiono na formę rozkazującą

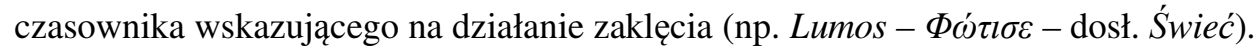
Nie inaczej jest w opisywanym wypadku. Colloportus zostaje przekształcone w polecenie $K \lambda \varepsilon \imath \delta \alpha \mu \pi \alpha \rho \omega ́ \sigma o v$, co odpowiada drugiej osobie trybu rozkazującego czasownika $\kappa \lambda \varepsilon l \delta \alpha \mu \pi \alpha \rho \omega ́ v \omega-$ zamknać i zaryglować (Zamknij się i zarygluj!).

Gdyby Harry Potter uczył się łaciny, nie miałby problemu z odgadnięciem działania czaru Sectusempra. Słowo pochodzi od łac. seco (secui, sectum) czyli siekać, ciać, ranić oraz od semper - zawsze. Znaczenie formuły nie zostało wyjaśnione jednak ani w oryginale, ani w polskim tłumaczeniu. Jest to również wyjątek w greckim przekładzie - to jedno z bardzo niewielu słów pochodzenia łacińskiego, które nie ulega przekładowi, a zamiast tego zostaje przetranskrybowane $(\Sigma \varepsilon \kappa \tau o v \sigma \varepsilon ́ \mu \pi \rho \alpha)$. 
Istnieje ku temu jednak bardzo logiczny powód - gdyby przełożyć formułę, tak jak w przypadku reszty zaklęć, to główny bohater niechybnie odgadłby jej działanie. Wtedy zastosowanie tej klątwy w pojedynku z Malfoyem na pewno nie można byłoby uznać za przypadkowe.

Podobnie jest w przypadku eliksiru Felix Felicis (od łac. Felix - szczęściarz; dosłownie jest to więc szczęście szczęśliwe lub szczęście przynoszace powodzenie), który nie jest tłumaczony na język polski. W języku greckim funkcjonuje transkrypcja $\Phi \dot{\lambda} \lambda l \xi \Phi \varepsilon \lambda i \sigma l \varsigma$, zapewne po to, żeby nie sugerować na wstępie jego działania.

W tym podrozdziale na uwagę zasługuje technika zastosowana przez Oıкovó $\mu$ ov przy przekładzie zaklęć w języku greckim i powody odstępstw od przyjętej taktyki.

\section{Wnioski}

Na podstawie powyższego zestawienia, można wyciągnąć następujące wnioski:

1. Imiona ludzkie nie są przekładane $w$ żadnym $\mathrm{z}$ omawianych tłumaczeń, a jedyny zabieg artystyczny dotyczy dostosowania ich formy do reguł języka (spolszczenie niektórych imion, zastosowanie transkrypcji w greckim przekładzie.

2. Imiona istot nieludzkich $w$ języku polskim ulegają kreatywnemu przekładowi. W języku nowogreckim zastosowany zabieg translatorski zależy od stopnia antropomorfizacji istoty. W przypadku stworzeń w dużej mierze przypominających ludzi, imiona są jedynie transkrybowane. W przypadku imion istot animalistycznych - powstaje kreatywne tłumaczenie.

3. Przydomki i pseudonimy są tłumaczone w obu wersjach językowych.

4. Nazwy geograficzne ulegają przekładowi w obu językach zależnie od ich przynależności do świata czarów lub świata mugoli. Tłumaczeniu poddane są jedynie nazwy czarodziejskich ulic.

5. W języku polskim przekłada się wszelkie bionimy.

6. W polskim przekładzie zwykle nie tłumaczy się neologizmów mających łacińską lub grecką podstawę, wobec czego neologizm ulega jedynie spolszczeniu. W greckim tłumaczeniu stosunek do łaciny jest zupełnie odwrotny niemal wszystkie nazwy łacińskie zostają przełożone na grekę.

7. Formuły magiczne (w większości wywodzące się z łaciny) zostają w języku greckim zapisane $w$ formie drugiej osoby trybu rozkazującego czasownika wskazującego na działanie zaklęcia. Pojawiają się uzasadnione wyjątki od tej reguły.

8. W przekładzie greckim od czasu do czasu pojawia się tendencja do rozbijania oryginalnie krótszych neologizmów na dłuższy ciąg wyrazowy.

9. Nazwy oryginalnie zawierające w sobie cząstkę -ing są przekładane w języku polskim za pomocą konstrukcji typu ,imiesłów przymiotnikowy + rze- 
czownik”, w greckim funkcjonuje konstrukcja ,rzeczownik + zaimek przymiotny + czasownik".

10. Grecka tłumaczka w przypadku problematycznych neologizmów wypracowała metodę stawiania słowa $\mu \alpha \gamma l \kappa o ́ s ~(m a g i c z n y)$ przed kłopotliwym rzeczownikiem.

11. W przekładzie polskim wyraźnie widać zabieg artystyczny, który można określić jako pseudoterminologizację.

12. W polskim tłumaczeniu widać czasem sugerowanie się nie tyle faktycznym znaczeniem oryginalnego neologizmu, co raczej jego fonetycznym podobieństwem.

13. W greckim przekładzie znacznie trudniej niż w polskim odnaleźć spójną taktykę tłumaczeniową. Nie wiadomo na przykład, dlaczego część nazw gatunków zwierząt posiada kreatywny przekład, a część terminów jest transkrybowana.

14. W ogólnym rozrachunku, greckie tłumaczki znacznie częściej korzystają ze stosowania tzw. kalek językowych niż autor polskiego przekładu, który preferuje mniej lub bardziej udaną kreatywną translację.

15. W obu przekładach występują nieścisłości, a tłumacze nie zawsze konsekwentnie podporządkowują się obranym taktykom translacyjnym.

16. O wiele łatwiej zrozumieć założenia polskiego tłumacza, ponieważ wielokrotnie opisuje je w dodatku do każdego tomu Kilka słów od tłumacza, czyli krótki poradnik dla dociekliwych. Greckie wydanie nie posiada podobnego słowniczka, przez co wszystkie techniki translatorskie muszą być po prostu zrekonstruowane na podstawie przykładów.

\section{Bibliografia podmiotu}

Rowling, J.K. 2001. Harry Potter and the Philosopher's Stone. Londyn: Bloomsbury. Rowling, J.K. 2002. Harry Potter and the Chamber of Secrets. Londyn: Bloomsbury. Rowling, J.K. 2004. Harry Potter and the Prisoner of Azkaban. Londyn: Bloomsbury. Rowling, J.K. 2000. Harry Potter and the Goblet of Fire. Londyn: Bloomsbury.

Rowling, J.K. 2003. Harry Potter and the Order of the Phoenix. Londyn: Bloomsbury.

Rowling, J.K. 2005. Harry Potter and the Half-Blood Prince. Londyn: Bloomsbury.

Rowling, J.K. 2007. Harry Potter and the Deathly Hallows. Londyn: Bloomsbury.

Rowling, J.K. 2000. Harry Potter i Kamień Filozoficzny. Przeł. Andrzej Polkowski. Poznań: Media Rodzina.

Rowling, J.K. 2000. Harry Potter i Komnata Tajemnic. Przeł. Andrzej Polkowski. Poznań: Media Rodzina.

Rowling, J.K. 2001. Harry Potter i Więzień Azkabanu. Przeł. Andrzej Polkowski. Poznań: Media Rodzina.

Rowling, J.K. 2001. Harry Potter i Czara Ognia. Przeł. Andrzej Polkowski. Poznań: Media Rodzina. Rowling, J.K. 2004. Harry Potter i Zakon Feniksa. Przeł. Andrzej Polkowski. Poznań: Media Rodzina. 
Rowling, J.K. 2006. Harry Potter i Książę Pótkrwi. Przeł. Andrzej Polkowski. Poznań: Media Rodzina. Rowling, J.K. 2008. Harry Potter i Insygnia Śmierci. Przeł. Andrzej Polkowski. Poznań: Media Rodzina.

Rowling, J.K. 2001. O Хó

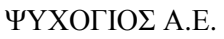

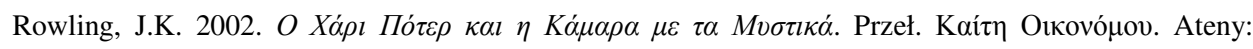
EK $\triangle \mathrm{O} \Sigma \mathrm{EI} \Sigma \Psi \mathrm{YXOГIO} \Sigma$ A.E.

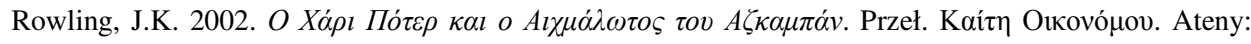
$\mathrm{EK} \Delta \mathrm{O} \Sigma \mathrm{EI} \Sigma \Psi \mathrm{YXOГIO} \Sigma$ A.E.

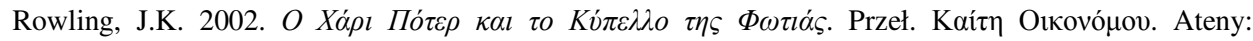
$\mathrm{EK} \Delta \mathrm{O} \Sigma \mathrm{EI} \Sigma \Psi \mathrm{YXO \Gamma IO} \Sigma$ A.E.

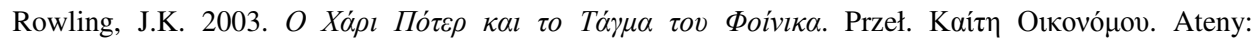
EK $\triangle \mathrm{O} \Sigma \mathrm{EI} \Sigma \Psi \mathrm{YXOГIO} \Sigma$ A.E.

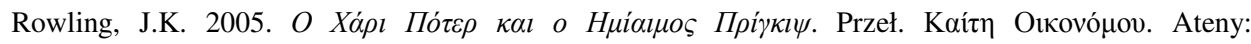
EK $\triangle \mathrm{O} \Sigma \mathrm{EI} \Sigma \Psi$ YХОГIO $\Sigma$ A.E.

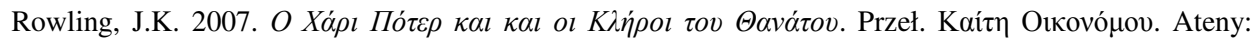
EK $\triangle \mathrm{O} \Sigma \mathrm{EI} \Sigma \Psi \mathrm{YXOГIO} \Sigma$ A.E.

\section{Bibliografia przedmiotu}

Chomik, M. i M. Krajewska. 2011. Od nominacji do kreacji. Rzecz o przekładzie neologizmów science fiction. Toruń: Wydawnictwo Naukowe Uniwersytetu Mikołaja Kopernika.

Linde-Usiekniewicz, J. 2002. Oxford. Wielki stownik angielsko-polski. Warszawa: Wydawnictwo Naukowe PWN.

Lukszyn, J. 1993. Tezaurus terminologii translatorycznej. Warszawa: Wydawnictwo Naukowe PWN.

Orliński, W. 2004. „Mugole kontra tumany” (wywiad z Andrzejem Polkowskim). Wysokie Obcasy. http://wyborcza.pl/1,75517,1890476.html [dostęp: czerwiec 2016].

Sierotwiński, S. 1986. Stownik terminów literackich. Teoria i nauki pomocnicze literatury. Wrocław: Zakład Narodowy im. Ossolińskich.

Trzaska, N.A. w druku. „Kreatywność tłumacza. O translacji neologizmów w powieści fantastycznej na podstawie polskiego i greckiego przekładu Harry’ego Pottera”. Publikacja pokonferencyjna ósmej edycji „Języka w Poznaniu”.

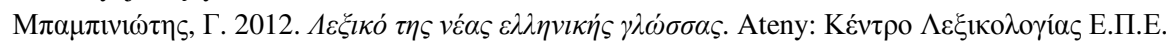

\section{Źródła internetowe:}

www.sjp.pwn.pl [dostęp: czerwiec 2016].

www.urbandictionary.com [dostęp: czerwiec 2016].

www.onomastyka.uni.lodz.pl [ dostęp: czerwiec 2016].

www.wyborcza.pl [dostęp: czerwiec 2016]. 